Universidad de Lima

Facultad de Comunicación

Carrera de Comunicación

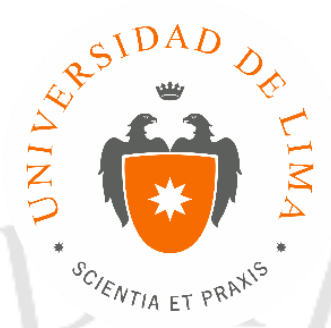

\title{
PRESERVACIÓN FÍLMICA EN PERÚ: UNA MIRADA A LOS PROYECTOS DE LOCALIZACIÓN Y DIGITALIZACIÓN DE LAS PELÍCULAS DE FRANCISCO LOMBARDI (1977-2000)
}

Tesis para optar el Título Profesional de Licenciado en Comunicación

\section{Lourdes Lorena Escala Vignolo}

Código 20100380

Asesor

Ricardo Bedoya Wilson 


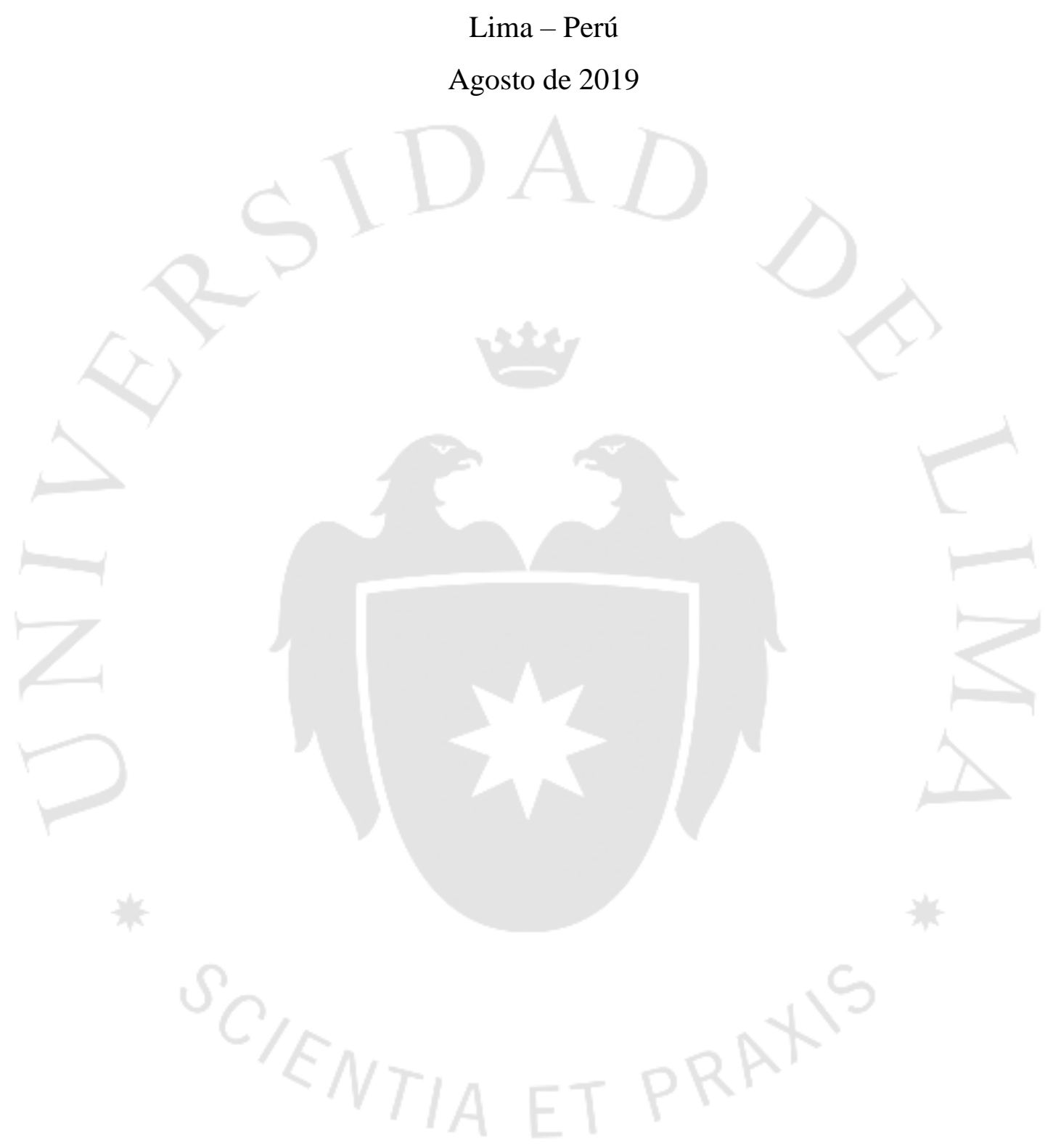


PRESERVACIÓN FÍLMICA EN PERÚ: UNA MIRADA A LOS PROYECTOS DE LOCALIZACIÓN Y DIGITALIZACIÓN DE LAS PELÍCULAS DE FRANCISCO LOMBARDI (1977-2000) 


\section{TABLA DE CONTENIDO}

1INTRODUCCIÓN..................................................................................1 2CAPÍTULO I: CONCEPTOS BÁSICOS SOBRE PRESERVACIÓN FÍLMICA . .6

2.1 Patrimonio fílmico ................................................................ 7

2.1.1Conexiones entre cine, memoria e historia............................. 7

2.1.2La protección patrimonial audiovisual ................................... 8

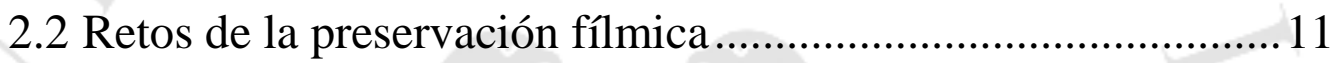

2.2.1Características técnicas de lo fílmico.........................................11

2.2.2Alcances sobre preservación digital .....................................14

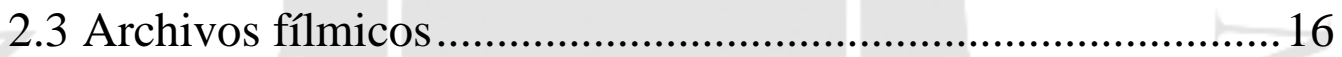

2.3.1 Breve historia de los archivos fílmicos....................................16

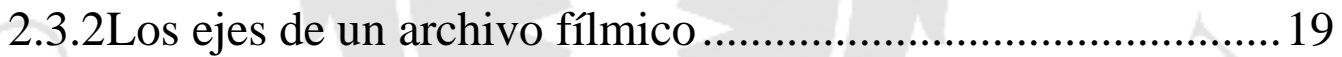

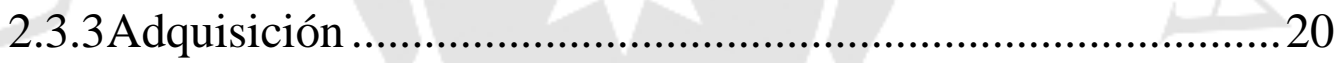

2.3.4Restauración, ética y autenticidad ..........................................21

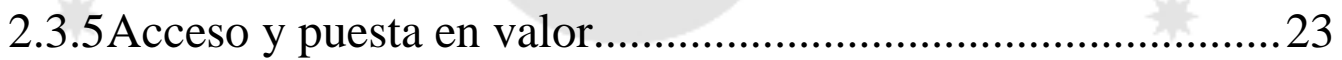

3CAPÍTULO II: PANORAMA DE LA PRESERVACIÓN FÍLMICA

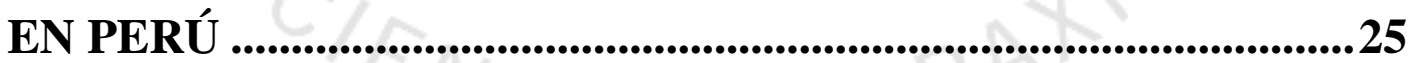

3.1 Repaso de archivos privados peruanos ......................................26

3.1.1 La Cinemateca Universitaria ...................................................26

3.1.2La Cinemateca de Lima .........................................................2

3.1.3Archivo Peruano de Imagen y Sonido (ARCHI) ......................28

3.1.4La Filmoteca de Lima y la Filmoteca PUCP ...........................29

3.2 Instituciones públicas en el Perú.................................................32

3.3 El caso de las películas de Lombardi............................................35 
3.3.1 Introducción .35

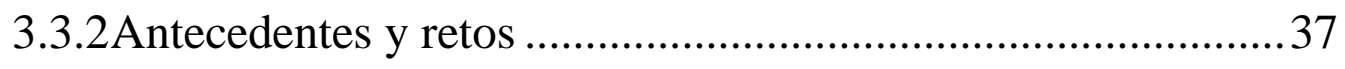

3.3.3Repaso cronológico de la ubicación de las películas ...............39

3.3.4Debate alrededor de la preservación digital..............................44

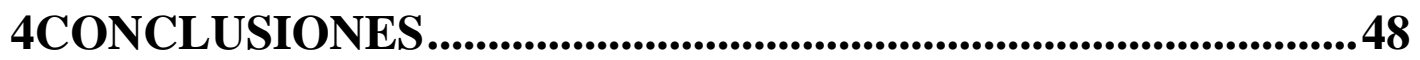

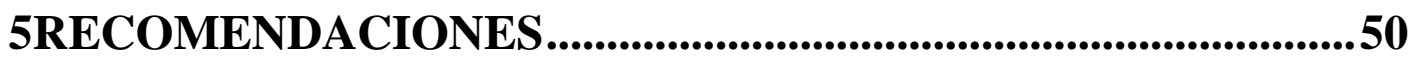




\section{ÍNDICE DE ANEXOS}

Anexo 1: Fichas de películas

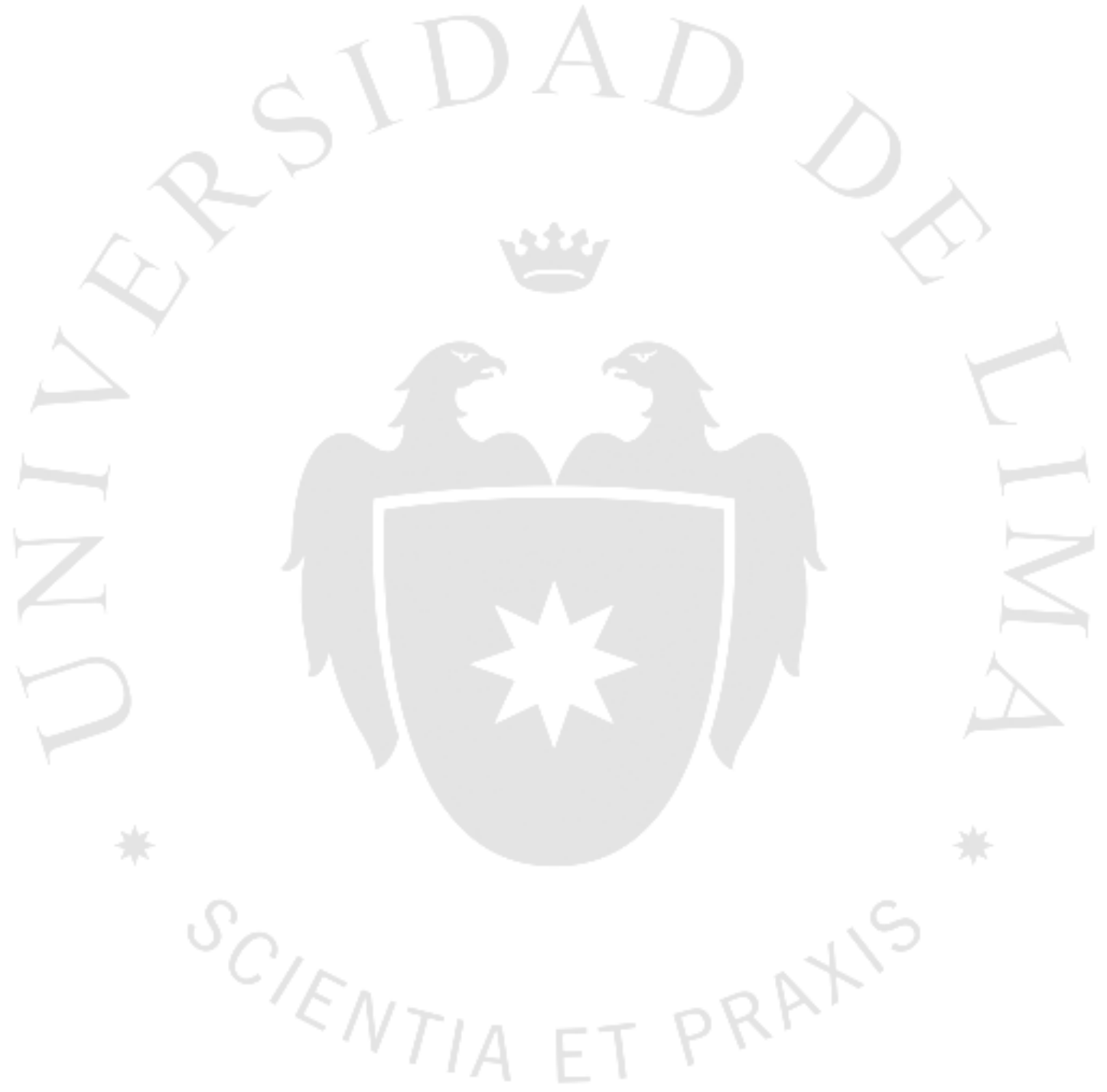




\section{INTRODUCCIÓN}

Heredamos de cada generación conocimiento - ya sea científico, histórico, artístico o sociológico - que se traduce en textos, utensilios, ilustraciones y otra serie de objetos, cuyo valor los coloca en la categoría de 'patrimonio cultural'. Sin embargo, esta transferencia lucha contra el factor del tiempo, destructor de la materialidad de los bienes. La fragilidad es variable de acuerdo con el soporte en cuestión y es más alta si se considera que ciertos artefactos no fueron ideados, en su momento, para perdurar.

El nitrato de celulosa ${ }^{1}$, material que, sobre todo en el periodo silente, sirvió como soporte para la impresión de imágenes en movimiento, posee patrones de deterioro súbitos, así como un nivel de inflamabilidad altísimo, lo cual lo vuelve susceptible a la auto-combustión. Posteriormente, se desarrolló el acetato de celulosa, cuyo principal problema de degradación es el síndrome del vinagre. Y aunque actualmente se ha desarrollado y normalizado el uso de lo digital, los retos que estos cambios de tecnología significan son otros, y dichos formatos no aseguran la preservación definitiva de las películas.

Creados para rodar, exhibir y desechar, los largometrajes, documentales, reportajes y otras grabaciones audiovisuales (incluso de carácter casero), son ahora una fuente de información de primera mano de una sociedad que, de otra manera, sería imposible de visualizar o de experimentar por nosotros o futuras generaciones. Como explica el conservador español Alfonso Del Amo, "[la imagen de un registro audiovisual] no solo es muy valiosa, sino que no puede ser sustituida por la documentación en papel. No hay ninguna descripción, e incluso ninguna forma combinada de descripción e imágenes fijas, que te dé lo que te da la imagen en movimiento" (Minichaplin, 2016). El gran reto de conservadores alrededor del mundo no es el de hacer perpetuar las obras en tanto objetos, sino la memoria colectiva: la de seleccionar, priorizar, catalogar, reparar y poner a disposición del público conocimiento que debe transcender.

El descuido o el aplazar acciones devendrían en la pérdida definitiva de un material invaluable que pertenece a la humanidad. Como manifiesta la Federación Internacional de Archivos Fílmicos (FIAF), las organizaciones públicas y privadas no

\footnotetext{
${ }^{1}$ Este es conocido comercialmente como 'celuloide'.
} 
solo se encargan de adquirir y custodiar las películas, sino de ponerlas a disposición de las actuales y futuras generaciones, sea por razones académicas como por placer.

Al discutir sobre la recuperación del patrimonio, nos enfrentamos también a la curaduría: ¿qué merece ser rescatado y legado? Si resultase económica y técnicamente factible, quizá todo registro audiovisual sería sujeto de conservación de las instituciones. Innegable es que tal tarea resulta irrealizable y que, por tal, la sociedad se ve obligada a establecer un 'orden de prioridad' sobre su patrimonio. Criterios diversos existen, aunque, por lo general, la necesidad responde a la relevancia histórica o artística de la pieza.

La repercusión académica en el ámbito internacional de Francisco Lombardi es medible, como lo demuestran las publicaciones sobre cine peruano o latinoamericano que lo mencionan: Writing National Cinema. Film Journals and Film Culture in Perú (Jeffrey Middents, 2009) o su aparición en catálogos como el Dictionnaire du Cinéma (Larousse, 2001), el cual coloca al cine peruano en un panorama internacional desde un punto de vista histórico. En el libro América Latina en 130 películas, editado por Uqbar y escrito por Jorge Ruffinelli, Perú aparece en dos momentos: en mención a la única película peruana nominada a los premios Oscar hasta este momento, La teta asustada (2009), y en mención a La ciudad y los perros (1985).

Asimismo, otras investigaciones académicas no giran precisamente alrededor del cine per se, sino que analizan determinadas obras de Lombardi desde una óptica sociológica. Por ejemplo, en el libro Political Violence and the Construction of National Identity in Latin America (Lambert \& Fowler, 2006), los autores ingleses, dedicados a los estudios latinoamericanos, otorgan un capítulo a las películas La Boca del Lobo (Francisco Lombardi, 1988) y a La vida es una sola (Marianne Eyde, 1993) como representativas de la configuración de la identidad peruana en el marco de la violencia política. De hecho, este es un tema muy recurrente en torno al estudio de las películas de Francisco Lombardi, sobre todo a aquellas que corresponden al periodo a investigar.

El presente documento responde a la necesidad de hacer visible el trabajo de la preservación de una labor que, incluso en otros ámbitos de mayor tradición, como la conservación de obras pictóricas, no ha tomado mayor fuerza en nuestro país. A través de la investigación de un material en vías de recuperación y cuyos protagonistas nos pueden brindar información de primera mano (facilidades para localizar el material a 
estudiar, así como del apoyo y el interés de los implicados directos), se recorre una línea de tiempo sobre las iniciativas que se han formulado en nuestro país y otras definiciones que rodean la restauración y que son todavía tema de debate.

El objeto de este estudio corresponde al material fílmico de largometrajes (y un mediometraje), por lo cual toma un segmento de la producción del director que va desde 1977, con Muerte al amanecer, hasta el año 2000, con Tinta roja. En términos contextuales, se inicia con la promulgación del Decreto Ley Nº19327, Ley de Fomento de Industria Cinematográfica, que rigió de 1972 a 1992, y continúa con la Ley №26370, Ley de la Cinematografía Peruana. Son un total de doce películas rodadas en material fílmico, cuyo rastreo y seguimiento resultan viables.

El repertorio seleccionado incluye títulos como La boca del lobo, La ciudad y los perros y Pantaleón y las visitadoras. Hoy en día es posible acceder a copias remasterizadas de su producción de largometrajes. Sin embargo, una 'remasterización' puede no ser más que un término. No se refiere a una 'restauración'. Al mismo tiempo, una restauración digital no es lo mismo que una restauración fotoquímica. Un proyecto de preservación involucra un plan a largo plazo y una serie de consideraciones de rescate, conservación y acceso tanto en materia técnica como política y cultural. Este es el caso que hemos tomado para analizar el panorama de la preservación en el Perú y la manera en que convergen las iniciativas de recuperación de dicho patrimonio cultural, sobre todo las de carácter privado; las que surgen desde la ciudadanía, en un país con precedentes irregulares en la materia.

La investigación, de tipo cualitativa, se vale de herramientas como la exploración de fuentes escritas, principalmente de documentos del Journal of Film Preservation ${ }^{2}$, manifiestos, textos oficiales institucionales, normativas y otros libros, catálogos y artículos ligados a la conservación audiovisual o a la historia del cine peruano. Asimismo, la metodología se sustenta en el trabajo de campo de observación de los archivos existentes y en las entrevistas en profundidad con Emilio Moscoso Manrique y a Francisco Lombardi Oyarzu, quienes actualmente gestionan los planes de recuperación de las películas.

\footnotetext{
${ }^{2}$ Es una publicación bianual de la FIAF. Más que un texto oficial o institucional, es un foro abierto a voces y prácticas de todo el mundo, tanto de las más ortodoxas, como de restauradores que tienen un enfoque mixto; o incluso de no especialistas relacionados al mundo del archivo fílmico. Las perspectivas van desde lo científico a lo social, administrativo, histórico y cultural.
} 
Cierro esta introducción agradeciendo a quienes me apoyaron de diversas maneras: a Norma Rivera, directora de la Filmoteca de la Pontificia Universidad Católica del Perú, quien me brindó una colección bibliográfica importante y espacios de lectura; a María Ruiz Vivanco, por otorgarme su tiempo y explicarme su labor en el archivo; a Emilio Moscoso Manrique, por concederme también muchos datos útiles con prontitud y grata disposición; a Francisco Lombardi Oyarzu, por contarme con tanto detalle sobre sus proyectos; y a Ricardo Bedoya, mi asesor de tesis.

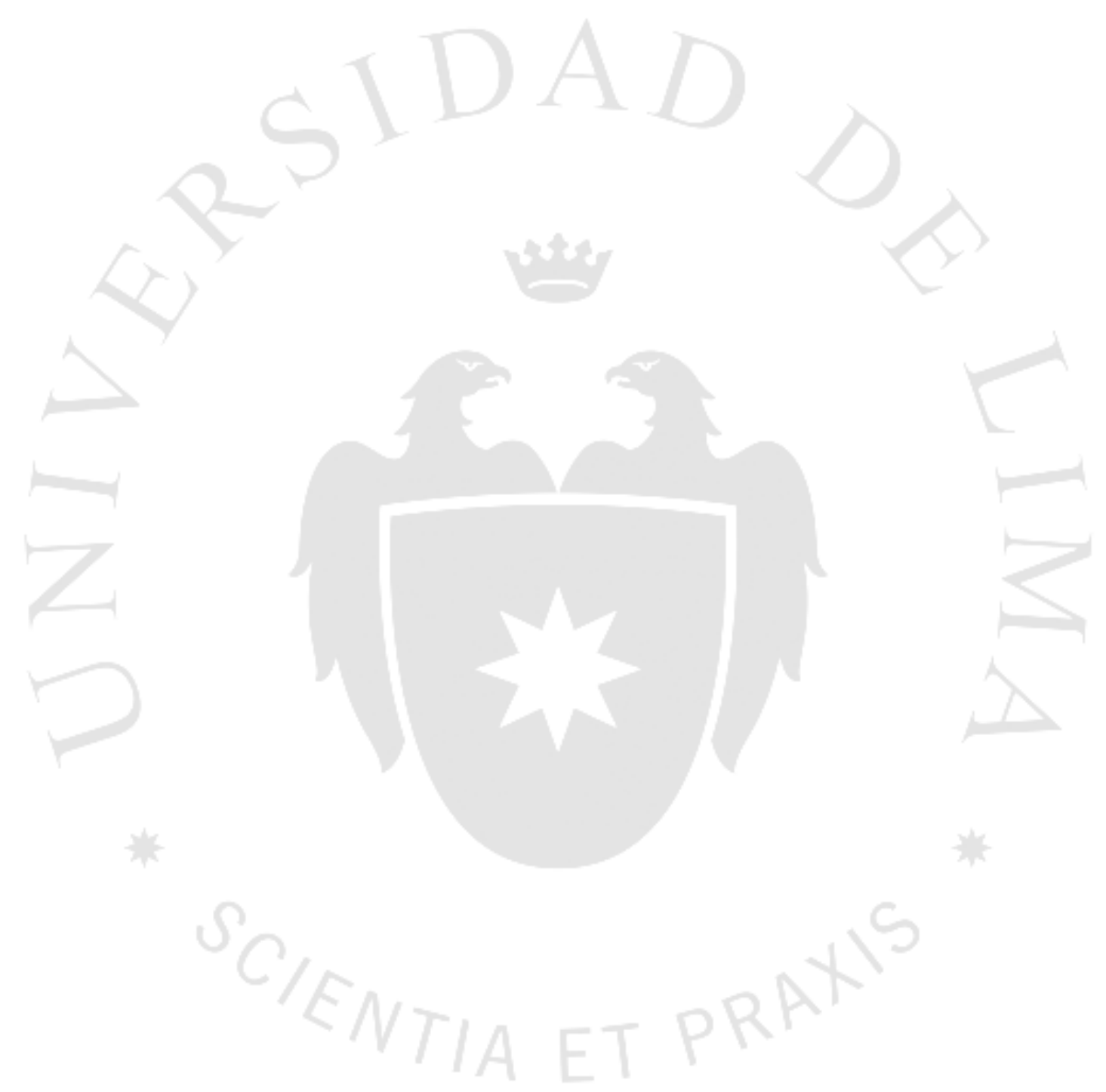




\section{RESUMEN}

Preservación fílmica en Perú: una mirada a los proyectos de localización y digitalización de las películas de Francisco Lombardi (1977-2000) toma como eje un caso de recuperación de material fílmico para continuar con el debate de la conservación audiovisual en nuestro país en el marco de la norma internacional. Se ponen en evidencia los retos de recuperar bienes que datan de fechas no tan lejanas —nos referimos a las décadas de 1970, 1980 y 1990-. Los desafíos se remontan a una negligencia tanto institucional como al interior del sector cinematográfico y se extienden a la actualidad, donde la obsolescencia, el abandono, el ambiente y los cambios tecnológicos digitales juegan en contra de este tipo de patrimonio en todas partes del mundo. 


\section{CAPÍTULO I: CONCEPTOS BÁSICOS SOBRE PRESERVACIÓN FÍLMICA}

Un par de términos clave contribuyen a comprender mejor la importancia de la preservación fílmica y cómo ésta se refleja en la conformación de archivos. La memoria y la historia constituyen valores primordiales del quehacer del conservador. En este capítulo, se hablará sobre la manera en que el cine se convierte en historia -o la reinterpreta- y cómo la historia misma se traduce en una memoria colectiva que sienta las bases para dirigir el presente en la sociedad.

Asimismo, lidiamos con el cine visto como patrimonio en un sentido cultural y político. Aunque en inglés sí se utilice mucho la denominación film heritage, en español prima el uso de 'patrimonio audiovisual'. Dada la acotación del tema de investigación, se optó por colocar en el título 'patrimonio fílmico'. Sin embargo, para efectos de la ubicación conceptual, puede que se hable indistintamente de lo 'audiovisual'.

Aunque la presente investigación no pretende ser una guía de carácter técnico, es importante conocer los retos que la preservación fílmica acarrea y el tipo de dilemas que formula para, en un análisis posterior de un caso, tener una visión crítica también desde esa perspectiva, en tanto nos ayudan a entender su viabilidad y eficiencia. Estos retos y amenazas son los que ponen de manifiesto la labor de los archivos, entidades clave que nos han permitido gozar de obras que han incluso sobrepasado la centuria y cuyo trabajo no se limita al de fungir de depósitos o almacenes. 


\subsection{Patrimonio fílmico}

\subsubsection{Conexiones entre cine, memoria e historia}

No es una idea nueva aquella que señala que la razón de ser del hombre se hallaría en los recuerdos. De hecho, el teórico francés Pierre Sorlin (1991) parte de la idea de que toda sociedad humana se configura de acuerdo con el recuerdo. Es decir, la conducta del ser humano se basa en una experiencia pasada de la sociedad a la que pertenece. A ello, él lo denomina "una memoria in absentia; sus miembros registran, como hechos vividos, de los que conservan la huella, sucesos de los que no han sido testigos" (p. 73). La memoria colectiva trasciende el tiempo y es, por ende, la historia en sí.

En esta "continua rendición de cuentas del pasado", dice Sorlin, hay también una revisión o reinterpretación de lo acontecido. Para el francés, la 'memoria sagrada' es aquella que no está sujeta a discusión, aquella tomada como verdad absoluta, aunque ésta sea tan ilusoria como transitoria. La historia y, por tanto, la memoria, deben estar siempre bajo constante escrutinio y ligadas al momento y a la sociedad que las interpreta. Pues "la noción de verdad no tiene, en este terreno, ningún sentido: la memoria es elección y ninguna elección es en sí misma verdadera o falsa, sólo los datos recogidos del pasado pueden reconstruirse con mayor o menor éxito en lo que a exactitud se refiere." (1991, p. 74).

La historia sirve como punto de partida para configurar el futuro y evaluar los cambios venideros. La historia es el punto medio entre lo que está sujeto a cuestión y lo que es fruto de una comunidad. Resulta también inmutable en cierto sentido, pues no debería responder a eventualidades y, más bien, servir de garantía de memoria para una sociedad. Pues, "en cierto sentido debe ser totalmente revisable y en otro, debe evitar la influencia de las modas o de los caprichos del momento." (Sorlin, 1991, p. 74). El reconocido y recientemente fallecido archivista Ray Edmondson (2004) había destacado en su libro Filosofía y principio de los archivos audiovisuales, el cómo preservar las obras se traduce en hacer sobrevivir el pasado. Y ya que está tan en boga el tema de lo “políticamente correcto", aprovecha para atacar la censura ultimando: "El pasado está fijado. No puede cambiarse" (p. 9). 
Y el cine ha demostrado su poder e importancia en la configuración de la historia en tanto, por ejemplo, ha sufrido también de las censuras a lo largo de su existencia. Desde tiempos inmemorables, "para demostrar su poderío, cada civilización aplastaba no solo a las personas, sino que destruía las obras y monumentos del país conquistado" (Marcos Recio, 2013, p. 15). Ahí tenemos tan solo el juicio protagonizado por la viuda de Stoker, quien hizo de todo por sacar del mapa Nosferatu (1922), la adaptación 'ilegal' de la novela de terror Drácula (Bram Stoker, 1897) de Murnau: en sus misivas, dejaba muy en claro que quería ver destruida hasta la última copia. Una manera de marcar el poder: hacer como si estos filmes ‘jamás hubiesen existido', lo cual ocurrió también con muchos títulos prohibidos y sacrificados durante la Alemania nazi.

\subsubsection{La protección patrimonial audiovisual}

El registro de uso de la palabra 'patrimonio', como patremonyo, originalmente, se remonta al año 1300. Su origen es el latín patrimonium, asociado también a términos como patronus (defensor, protector) y, en primera instancia, a la raíz pater (padre) (Corominas y Pascual, 1984, p. 335). La esencia del término corresponde justamente a un conjunto de bienes heredados de los padres. En el caso nuestro, en que el término se enfoca en un patrimonio de tipo histórico, la acepción adoptaría ya un carácter más amplio: la defensa de los bienes se torna empresa nacional — e incluso mundial — dado que estos fueron 'legados' por antepasados en común; aquellos que conforman la cronología de la humanidad como expresión social, política, científica, cultural.

En ese sentido, el patrimonio histórico es la "suma de las aportaciones de cada periodo histórico, por lo que acaba siendo por fuerza el reflejo de la identidad de los pueblos" (Hidalgo Goyanes, 2013, p. 54)

Un concepto importante es el del valor 'abstracto' (no es, a priori, económico) que toma dicho bien, sea material o inmaterial, lo cual lo torna objeto de protección legal. Aunque la salvaguarda de determinados monumentos, piezas artísticas, estructuras arquitectónicas, entre otros, sean más visibles desde el punto de vista legislativo, existen también decretos que señalan a las obras audiovisuales (a veces incluidas en lo 'documental') como patrimonio. 
La institución internacional de mayor envergadura que ha hecho un llamado de atención sobre el asunto de lo audiovisual y ha llevado a cabo diversas iniciativas ha sido la UNESCO, la cual en 1980 publicó un documento titulado Recomendación sobre la Salvaguardia y la Conservación de las Imágenes en Movimiento tras celebrarse la 21 va. Conferencia General de la Organización de las Naciones Unidas para la Educación, la Ciencia y la Cultura, en Belgrado, del 23 de septiembre al 28 de octubre de ese mismo año. Entre sus puntos más importantes, destacan las imágenes en movimiento como portadoras de valor "educativo, cultural, artístico, científico e histórico, características de la sociedad actual" y, por su "forma de registro, testimonios únicos de la historia" (UNESCO, 1980). Bajo dichos fundamentos, la UNESCO exhorta a las naciones a tomar medidas que aseguren la salvaguarda de estos materiales vulnerables, tanto como se hace efectiva la defensa de otro tipo de bienes culturales, así sean estos de producción nacional o internacional.

Para virar el tema en foco de interés internacional, desde el año 2006, la UNESCO instauró el Día del Patrimonio Audiovisual, cuya fecha es el 27 de octubre. Entre uno de sus principales objetivos, destaca la accesibilidad de los archivos (Hidalgo Goyanes, 2013, p. 57).

Existe además el término 'patrimonio mundial', el cual es promovido por la UNESCO como una manera de destacar la relevancia común que tienen ciertos bienes para el hombre, pues estos trascienden culturas, idiomas y fronteras, y constituyen una historia en conjunto de la humanidad. Aunque el determinar qué bienes se adscriben a tal categoría es también materia de debate, la UNESCO incluye al patrimonio audiovisual en lo que corresponde a la Memoria del Mundo, un programa de carácter internacional que involucra la inscripción de bienes de cierta importancia en un registro que otorguen a aquellos un estatus de preservación. Dicha medida incluye: asistencia práctica a archivos, promoción al acceso a través de copias digitales y catálogos en línea, y a la difusión de información para crear conciencia sobre el patrimonio documental (Edmondson, 2002, p.8).

En cuanto a nuestro país, dentro de la legislación pertinente en materia patrimonial, encontramos los siguientes documentos:

Ley N² 28296, Ley General del Patrimonio Cultural de la Nación.

Ley Nº 29565, Ley de Creación del Ministerio de Cultura. 
Ley N $\mathrm{N}^{\mathrm{O}}$ 25905, Ley de Depósito Legal en la Biblioteca Nacional del Perú y su Reglamento, aprobado mediante Decreto Supremo Nº17-98-ED.

Ley N ${ }^{\circ}$ 25323, Ley de Creación del Sistema Nacional de Archivo.

Decreto Ley N ${ }^{\circ}$ 19414, Ley de Defensa, Conservación e Incremento del Patrimonio Documental de la Nación.

Ley N $\mathrm{N}^{\mathrm{3}}$ 30570, Ley General de la Biblioteca Nacional del Perú y su Reglamento, aprobado mediante Decreto Supremo No 010-2017-MC.

Los Reglamentos de Organización y Funciones del MC, IRTP, AGN y BNP.

Ley $N^{\circ}$ 26370, Ley de la Cinematografía Peruana (promulgada en 1994) y sus respectivas modificatorias.

De acuerdo con la Ley General del Patrimonio Cultural de la Nación, Ley $\mathrm{N}^{\circ} 28296$, se inscriben los documentos cinematográficos como bienes muebles, específicamente como patrimonio cultural bibliográfico documental, y que las entidades encargadas de la salvaguarda del patrimonio son el Ministerio de Cultura, la Biblioteca Nacional y el Archivo General de la Nación. La Ley №26370, Ley de Cine, y sus modificatorias hacen hincapié en la preservación y en la creación de una Cinemateca Nacional, medida que no se ha hecho efectiva. De igual manera, la Ley No30570, de la Biblioteca Nacional del Perú, delega a dicha institución la labor de archivo audiovisual, de manera que sus funciones 'tropiezan' con las atribuidas a la actual DAFO.

Dentro de los planes por las celebraciones del Bicentenario de la Independencia del Perú, se habla de la implementación de una Cinemateca en Cusco; proyecto que, de acuerdo con el titular de la Dirección Desconcentrada de Cultura de Cusco, Luis Nieto Degregori, se halla en etapa de evaluación técnica (Andina, 2018). Sin embargo, existe aún mucho escepticismo sobre el verdadero avance de la propuesta, sobre todo cuando no es la primera vez que se escucha algo similar en los medios.

Para ampliar la información vinculada a las leyes, se recomienda acercarse al informe elaborado en el 2015 por Christian Wiener para el Ministerio de Cultura, en el 
cual se comenta de manera más o menos detallada las consideraciones, vacíos y omisiones legales que afectan la labor de la conservación fílmica en nuestro país. ${ }^{3}$

\subsection{Retos de la preservación fílmica}

\subsubsection{Características técnicas de lo fílmico}

Para comprender en qué se trabaja cuando se habla de preservación fílmica es necesario mencionar a qué material nos referimos y qué características posee. De acuerdo con Alfonso del Amo García (2016), quien fue Jefe de Conservación de la Filmoteca Española, sin ir más lejos —o tener que remontarnos a todo el desarrollo histórico del cine-, basta decir que este nació como un sistema de arrastre de película: "sistema que transforma el impulso motor rotatorio que mueve la película, en un movimiento lineal con alternancias de avance y parada, sincronizado con el movimiento de un obturador giratorio que impide el paso de la luz cuando la película no está perfectamente parada" (p. 9). En términos concretos, el cine era la proyección pública de fotografías sucesivas que daba la sensación de movimiento.

En la dimensión de la conservación, para del Amo García habría que tener en cuenta estas dos cualidades de la constitución física de las obras cinematográficas:

1. Son contenidas en dos soportes: los negativos (originales) y los positivos (copias para ser proyectadas); los cuales poseen sus propias características y se manejan de diversa manera. Aunque se manipulan distinta e independientemente, forman parte de una unidad cuyo deterioro es nefasto para el rescate de la película.

2. La película está formada por dos capas: un soporte de plástico transparente y una emulsión fotográfica compuesta por gelatinas naturales y sustancias fotosensibles (del Amo García, 2016, p. 10).

En dicho sentido, el deterioro se daría en dos momentos:

\footnotetext{
${ }^{3}$ El informe se cita más adelante y se incluye en la sección de Referencias. Para leerlo, se puede seguir el enlace: http://www.infoartes.pe/publicacion-estudio-y-propuesta-sobre-conservacion-y-difusion-delmaterial-cinematografico-y-audiovisual-peruano-de-christian-wiener/
} 
1. Durante la proyección, debido al sistema de arrastre, el desgaste de la película era ineludible. Estos sucesivos arranques y pares de fotograma en fotograma pueden incluso destruir los positivos.

2. Durante el tiempo de vida del soporte plástico, debido a su inherente inestabilidad química. En todos ellos la contracción es un común denominador, aunque el deterioro es diverso de acuerdo con el tipo de soporte.

En cuanto a los soportes, habría que diferenciar entre el nitrato de celulosa plastificado, desarrollado a partir de investigaciones iniciadas por Christian Friedrich Schömbein en 1846, y los acetatos de celulosa y poliéster. El nitrato de celulosa es muy peligroso debido a su alta inflamabilidad. Se utilizó en los inicios del cine e Eastman Kodak dejó de fabricarlo en 1951. Los soportes a los que nos referiremos con mayor frecuencia son el triacetato de celulosa plastificado y el poliéster, los cuales fueron desarrollados como soportes de seguridad (las películas llevaban impresas el rótulo 'safety film' para diferenciarlas de aquellas copias en nitrato de celulosa).

A pesar de no ser auto-combustibles, apenas diez años más tarde, las copias en triacetato de celulosa empezaron a mostrar señales de descomposición. Como bien explica del Amo García (2016),

La degradación iba acompañada con una intensa producción de ácido acético, por lo que la nueva "enfermedad" fue caracterizada como síndrome de vinagre. En pocos años, las condiciones estándar de conservación en archivos $\left(18^{\circ} \mathrm{C}\right.$ y $\left.50 \% \mathrm{HR}\right)$ se revelarían como poco eficaces para la conservación cultural (a plazo indefinido) e incluso para la comercial. En esas condiciones (con todo muy difíciles y costosas de conseguir en ciudades húmedas y cálidas) el síndrome de vinagre se ralentiza, pero termina por aparecer y dañar los materiales (p. 12).

Esta degradación afecta fuertemente las cualidades cromáticas de la película, información que inevitablemente se pierde con el tiempo y se acentúa en inadecuadas condiciones de conservación. Debido a que se trata de un cambio químico, no es posible revertir este proceso. Sin embargo, sí existen otros mecanismos para devolverle a un filme su 'esplendor cromático'. De acuerdo con el conservador italiano Paolo Cherchi Usai, una de las oportunidades en el campo de la restauración fílmica que brindan las tecnologías digitales es una mejor corrección de color (Arcoiris TV Channel, 2004). 
Otro asunto es el de las emulsiones adheridas al soporte. Sin ir a detalles químicos, estas emulsiones están compuestas por una fina capa de gelatina que mantiene en suspensión a los haluros fotosensibles y otros agentes que forman la imagen. Las gelatinas son de origen orgánico y poseen una gran estabilidad, a menos de que se les sometan a temperaturas mayores a $40^{\circ} \mathrm{C}$ y a ello se le sume otras condiciones desfavorables de almacenamiento como falta de ventilación. Todo esto fomentaría la aparición de microorganismos, los cuales son imposibles de eliminar permanentemente (del Amo García, 2016, p. 15).

Para el año 2006, María Rita Galvão, quien fue directora de la Cinemateca Brasileira, publicó una encuesta aplicada en archivos fílmicos iberoamericanos. En ella, estos espacios brindaron información sobre los daños que padecían sus acervos. Estos incluyeron deterioros irreparables; daños mecánicos como rayas, pliegues, perforaciones rotas, hongos y bacterias (que siempre han sido un problema serio para los archivos y que, gracias a la instalación de bóvedas climatizadas y con control de humedad, han podido hacerle frente). El problema que más se reportó, y cuya prioridad se destacó, fue el síndrome del vinagre. Menos frecuente era la hidrólisis de nitrato ${ }^{4}$. Entre otros asuntos prioritarios se mencionaron, en el siguiente orden: el encogimiento, el desvanecimiento de la imagen en blanco y negro, el desprendimiento del soporte, la decoloración de las películas, el abombamiento, la cristalización del soporte, la transferencia de brillo y la licuefacción de la emulsión (p. 48).

El asunto del deterioro químico de las películas es un área de investigación amplísimo y de carácter muy técnico. Los retos son diversos y dependen de los soportes. Pero queda claro que requieren de un almacenamiento en condiciones especiales, así como de un tratamiento a manos de un grupo de profesionales para asegurar su perdurabilidad y una sostenibilidad a nivel institucional. Este es el trabajo principal al que se abocan las filmotecas, a las que, en las últimas décadas, se les ha sumado el desafío de la preservación digital.

${ }^{4}$ Término químico que se refiere al desdoblamiento de una molécula por acción del agua (RAE). 


\subsubsection{Alcances sobre preservación digital}

Vale precisar que, cuando hablamos de preservación digital, nos topamos con dos posibilidades: 1. Que el material sea nativamente digital; es decir, que ya haya sido grabado en tal formato, o que 2. El material haya sido grabado en acetato, poliéster, celuloide u otro y que se haya realizado una copia en digital, sea para distribución o como una copia de seguridad para preservar.

Las primeras cámaras digitales aparecieron a finales de la década de 1990 y es la tendencia general en nuestros días en las grabaciones de películas, debido a las reducciones que la tecnología otorga en cuanto a costos y tiempo, así como a las facilidades en la conformación de efectos, en condiciones durante el rodaje y en las técnicas de edición. De igual manera, sacar copias digitales de películas en $16 \mathrm{~mm}$ o $35 \mathrm{~mm}$ es común debido a que es la norma de exhibición, ya sea en salas o por los servicios de streaming de películas (Perlmutter, 2017, párr. 4).

Existe una suerte de fe ciega en lo digital. Surge la sensación en las personas de que, cuando sus archivos y carpetas son almacenados en un disco duro, tienen todo bajo control. Otros no se fían plenamente de esto y suben su información a 'la nube', casi como si se hablara de un concepto abstracto. En ambos casos, la perdurabilidad va a depender del soporte. Y dicho soporte no es más que una serie de materiales que sucumben de igual manera a la degradación y que son amenazados constantemente por la corrupción de archivos, si no es de todo el sistema. El problema de la estabilidad resurge.

De acuerdo con un artículo de IEEE, en lo que a la conservación digital en archivos se refiere, se recurre a una tecnología de almacenamiento de cintas magnéticas conocidas como LTO, cuyas siglas en inglés corresponden a linear tape-open. Si bien este material no es tan longevo como la película de poliéster, si se almacena correctamente, puede durar entre treinta y cincuenta años. El inconveniente de este sistema es la obsolescencia, pues cada cierto tiempo los fabricantes desarrollan una nueva versión de estas cintas, las cuales tornan obsoletas las anteriores. De esta manera, los archivos se ven obligados a migrar de tecnología y a invertir una cantidad muy grande de dinero para no perder la información (Perlmutter, 2017, párr. 6). De igual manera, Matthew Dessem (2014), del portal The Dissolve, había ya señalado este problema. El 
tema de los altos costos que igual demanda la preservación de los archivos digitales había sido mencionado en torno al 2007, cuando el Concejo de Tecnología y Ciencia de La Academia publicó The Digital Dilemma y, junto al Library of Congress's National Digital Information Infrastructure and Preservation Program (NDIIPP), The Digital Dilemma 2, informes sobre los problemas que enfrentan los grandes estudios y los archivos en torno a esto.

La muy diversa información y datos que se hallan en estos artículos, evidencian que no existe un consenso sobre la duración de soportes digitales, ni se sabe de qué manera podrían, en un futuro, seguir mutando las tecnologías, de tal forma que se torne empresa imposible de seguir reproduciendo ciertas películas grabadas que solo reconoce, por ejemplo, tal o cual códec.

Hay, también, quienes son mucho más conservadores con el asunto digital. Para del Amo García (2006), parece ser el material fotoquímico no solo el que provee de un mejor pronóstico de preservación por la materialidad de la imagen, sino el medio que hace que una película sea llamada como tal, al ofrecer una experiencia completa de lo que es ver cine:

La realidad (digital o no) es que, hoy, las películas producidas digitalmente no tienen asegurada ninguna conservación; y para asegurarles alguna conservación hay que reproducirlas sobre emulsiones fotoquímicas. Pero conservar los materiales no es suficiente; hay que reproducirlos. Y es necesario reproducir todas las características que forman las películas (p. 19).

Se enfrentan dos posturas: la digital, que supone el uso del LTO en los archivos, y la analógica, que exige contar con copias de $35 \mathrm{~mm}$ de todas las películas. Otra clara partidaria de la segunda posición es Paula Félix-Didier, directora del Museo del Cine Pablo Ducros Hicken, en Buenos Aires, quien escribió en la investigación sobre memoria del cine argentino La imagen recobrada (2015) sobre cómo las características físicas y mecánicas de lo fílmico destacan por su estabilidad, pues estas se mantienen desde la introducción del sonoro (es decir, refiriéndose probablemente ya al desarrollo de la película de acetato). Para ella, el argumento más sólido es la longevidad del soporte, pues “(el fílmico) es el que garantiza la supervivencia de las obras audiovisuales por más tiempo" (p. 22). 


\subsection{Archivos fílmicos}

Si bien la historia de la preservación fílmica puede ser vista desde el punto de las colecciones privadas, desde los alcances científicos o desde la industria en sí, este es un enfoque institucional. Partimos de la formalización de la preservación fílmica en la conformación de cinematecas ${ }^{5}$ alrededor del mundo, las cuales se inscriben a un canon técnico y de relaciones institucionales. En ese sentido, resulta ineludible hablar de la Federación Internacional de Archivos Fílmicos (FIAF), primer gran conglomerado de carácter mundial y que ha contribuido a la estandarización de las condiciones de preservación, investigación e intercambio de conocimiento.

Tampoco habría que olvidar mencionar sobre qué hablamos cuando nos referimos a la preservación fílmica; es decir, al trabajo concreto de un archivo: actividades diarias, objetivos finales, etapas de la restauración de una película, entre otros.

\subsubsection{Breve historia de los archivos fílmicos}

Aunque la preservación fílmica aparezca de manera más extendida en el ámbito internacional desde hace relativamente poco, en realidad se empezó a hablar de archivos hace unos años tras la invención del cine. Podría decirse que un pionero de la documentación audiovisual fue un fotógrafo y cineasta polaco llamado Boleslaw Matuszwski, quien en una fecha tan temprana como 1908 hablaba ya del valor histórico de los documentos cinematográficos y de la necesidad de conservarlos:

En sus actividades y en sus escritos teóricos, muchos años antes de la aparición el primer archivo cinematográfico, sienta las bases de la conservación cinematográfica, determinando que la actividad de coleccionar películas debe ser un servicio público, en el que se impliquen distintos organismos de la Administración; asimismo señala por primera vez a la idea de que debe haber un depósito legal para la cinematografía, propone que los archivos estén abiertos al público y prevé además salas de proyección. Y, anticipándose a las ideas actuales, da prioridad a la conservación de los negativos (Del Valle Gastaminza, 2013, p. 113).

\footnotetext{
${ }^{5}$ Nos referiremos a estas indistintamente como cinetecas, filmotecas, archivos fílmicos, archivos de imágenes en movimiento y similares.
} 
Los postulados de Matuszwki estaban enfocados en el cine documental como un registro histórico de la realidad, un elemento de uso social y un testimonio de valor científico; por lo cual primó para él su carácter educativo y no el artístico. El cine de ficción no era su área de estudio ni de desarrollo como camarógrafo (Staszczyszyn, 2016). De igual manera, alrededor de 1915, el inventor W.K.L. Dickson y el poeta Vachel Lindsay, también se pronunciaron sobre la importancia del establecimiento de colecciones fílmicas. Aunque estos dos personajes no compartían las mismas ideas sobre lo que era coleccionar, "todas sus peticiones se remontaban a la importancia de preservar la identidad nacional y registrar la historia” (Coco y Romero, 2017, p. 48).

Sin embargo, el interés por preservar las películas no era aún extendido, y hubo incluso una serie de destrucción de material que no era considerado importante, como se dio por el rechazo de cine de barraca de feria alrededor de 1951, y en 1927, tras la aparición de las películas sonoras (Del Valle Gastaminza, 2013, p. 114). El primer archivo fílmico en constituirse fue el Svenska Filmsamfundet, fundado en 1933 en Estocolmo. Hasta ese momento, las colecciones de películas que existían previamente servían como depósitos legales o propósitos utilitarios netamente educativos, militares o religiosos; pero su rol no se debía a un interés por conservar el cine (Daudelin y Le Roy, 2008, párr. 1).

Posteriormente, nació el Reichsfilmarchiv de la Alemania nazi, el primero de los cuatro archivos fundadores de la FIAF, una alianza pionera en la institucionalización de la preservación de películas. El Reichsfilmarchiv fue establecido el 29 de enero de 1934, "aunque fue oficialmente inaugurado (por el mismo Hitler) en febrero de 1935, para cuando ya poseía alrededor de 1200 películas de 'importancia cultural o artística"” (Dupin, 2013, p. 44). En 1935, Frank Hensel, el nuevo director de la institución, quien hablaba muy bien inglés y viajó mucho en su juventud, sería muy útil en la conformación de relaciones con archivos internacionales. Ese mismo año, New York City's Museum of Modern Art (MoMA) estableció su archivo fílmico, "esencialmente una librería de préstamo de copias de películas, con Iris Barry a la cabeza" (Coco y Romero, 2017, p.48). Por otro lado, en Inglaterra, el British Film Institute (BFI) fundó la división del National Film Archive (llamado National Film Library hasta 1955), con Ernest Lindgren como curador. Los intercambios entre estas instituciones se iniciaron de inmediato.

Iris Barry y su esposo John Abbott, del MoMa Film Library, viajaron a Europa para iniciar conversaciones directas con sus contrapartes en dicho continente. A inicios 
de junio de 1936, los Abbott dejaron Londres y arribaron a París, donde conocieron a Henri Langlois. El muchacho de sólo veintidós años había fundado el Cercle du Cinema junto con su amigo Georges Franju el año previo y ya estaba adquiriendo una colección de, principalmente, clásicos del cine mudo, gracias al soporte financiero de Paul Auguste Harlé, director de la revista La Cinématographie française (Dupin, 2013, p. 47). Gracias a la formación de aliados en otras partes del mundo para solventar y sostener una idea de un archivo fílmico, Langlois registra como una asociación privada, en septiembre de 1936, la Cinémathèque française.

A su retorno a Estados Unidos, los Abbott manifiestan su admiración por el Reichsfilmarchiv, el cual Iris Barry definió como un archivo "amplio y muy bien organizado" (Dupin, 2013, p. 47) y afianzan sus lazos con la Cinémathèque française, cuyo primer intercambio oficial fue una copia de Le Voyage dans la Lune (Georges Méliès, 1902), cuya proyección Langlois organiza y al que asiste el mismo Méliès (FIAF). Las preocupaciones en este intercambio se extendieron también a posters, programas y otros materiales impresos.

En junio de 1937, Langlois escribió un artículo para Cinématographie française sobre el desarrollo de archivos fílmicos. Sus lazos con otras cinematecas alrededor del mundo fueron surgiendo también, sobre todo con las de Milano, Bruselas y Basel (la futura Cineteca Italiana, Cinèmathèque Royale de Belgique y Cinémathèque Suisse, respectivamente).

Es ya en una carta de Langlois a Abbott, el primero de junio de 1938, que confirma un acuerdo inicial para crear una Federación Internacional de Archivos Fílmicos, suscrita y también esbozada por Olwen Vaughan (BFI) y Hensel (Reichsfilmarchiv). Esta tendría como meta la preservación de filmes, compilación y proyecciones para propósitos no comerciales, sean pedagógicos o artísticos (Dupin, 2013, p. 53).

Actualmente, la FIAF cuenta con ochenta y nueve miembros (archivos) y setenta y siete asociados (instituciones no comerciales que cuentan con algún programa en preservación) en setenta y cinco países. Es la comunidad más reconocida a nivel mundial en cuanto a preservación fílmica. En nuestro país, solo la Filmoteca de la Pontificia Universidad Católica del Perú (Filmoteca PUCP) es miembro.

En la región latinoamericana, el archivo más antiguo es el uruguayo, el cual en realidad nace como Departamento de Cine Arte del Sodre el 16 de diciembre de 1943, y 
cuyas funciones se enmarcaban en las de una cinemateca europea y cineclub, por lo cual en 1945 pasa a formar parte de la FIAF. Hoy es el Archivo Nacional de la Imagen y la Palabra - SODRE. Posteriormente, aunque también en la década de 1940, surgen la Cinematecas Brasileira (1946) y la Cinemateca Argentina (1949), la cual desde 1967 adopta la forma jurídica de Fundación. La filmoteca más nueva en la región es la Cineteca Nacional de Chile, fundada en marzo de 2006. Es precedida por la Filmoteca PUCP (Galvão, 2006, p. 43), aunque sabemos que en realidad sus orígenes se remontan a la antigua Filmoteca de Lima que existía desde 1986.

\subsubsection{Los ejes de un archivo fílmico}

Especialistas como Edmondson (1995) explican que una cineteca es un organismo que funciona gracias a "bloques de construcción" o "componentes esenciales" (p. 55) o, como indica Cherchi Usai (2004), que cumplen, de manera sincrónica, con tres directrices principales:

- Adquisición: Involucra la conformación de una colección y la recepción de nuevos materiales que enriquezcan el conocimiento del cine. En este punto entra a tallar la política de colección de un archivo.

- La conservación: se refiere a la preservación y al conjunto de actividades enfocadas en la estabilización del material (es decir, en detener su deterioro), duplicación de copias, adquisición de nuevos elementos de proyección y de conservación, etc. Esta labor se lleva a cabo de la mano de laboratorios especializados.

- El acceso: Cherchi asegura que "un filme no es verdaderamente restaurado sino hasta que se hace accesible al público" (Arcoiris TV Channel, 2014). Menciona que acceso significa proyección; y que éste es objetivo último de una cineteca bajo el cual todas sus acciones se dirigen (o deberían dirigirse). Sin embargo, como veremos más adelante, es posible también explorar otras modalidades de acceso.

Las actividades que llevan a cabo los archivos se desprenden de estos tres ejes. Sin embargo, las acciones que se ejecuten dependerán también del tamaño de la 
institución y de sus posibilidades económicas, técnicas, profesionales y tecnológicas. De igual manera, sus alcances podrían extenderse. De acuerdo con la investigación de Galvão (2006), previamente citada, se confirma que estos espacios desarrollan la labor de documentación y de exhibición y que, además, fomentan otras actividades culturales. Entre estas, se encuentran, por tan solo nombrar algunas: el asesoramiento a otros archivos y el intercambio de conocimiento, la recuperación de materiales fílmicos y fotográficos de terceros, la publicación de revistas o textos especializados, la cesión de espacios para la investigación, la organización de conferencias y cursos o talleres de cine y la promoción de festivales (p. 55).

\subsubsection{Adquisición}

De acuerdo con los cálculos del conservador Paolo Cherchi Usai (2004), la restauración de un largometraje de duración media y sin banda sonora, en condiciones medianamente aceptables, costaría alrededor de cincuenta mil euros. Una cineteca de dimensiones medianas cuenta con once mil o veinte mil filmes, por lo cual restaurar todos estos filmes significaría una inversión económica muy grande que supera, en demasía, las posibilidades de cualquier institución pública o privada. De ahí que la curaduría, como la toma de decisión sobre qué cosas se restaura y con qué objetivos, sea un factor crucial. Esta selección es complicada, pues en teoría todas las películas deben ser restauradas. Sin embargo, se hace necesaria la identificación de criterios. Como Cherchi recalca, en esta actividad "está involucrada una estrategia cultural”, pues la decisión sobre qué priorizar "es decidir qué debe ser puesto a disposición del público del futuro" (Arcoiris TV Channel, 2004).

En esta etapa, entra en juego la política de conservación, un documento que detalla la misión de la institución, el por qué existe, qué labores realiza y otros detalles como la determinación de los parámetros del material a coleccionar, de aquel que será dado a otra institución y cuáles son las circunstancias que determinan que un material sea destruido (Burrows, Cherchi, Giuliani, Trainor y Wengström, 2013, p.27).

A eso habría que sumar las labores de preservación fílmica que se extienden a los materiales asociados a la producción y a la distribución. En la encuesta del 2006, realizada a los archivos latinoamericanos, se mencionan, entre los documentos que resguardan 
dichas instituciones: colecciones de libros, periódicos, afiches, guiones, objetos museológicos (colecciones tecnológicas), fotografías, recortes de prensa, entre otras (Galvão, 2006, p. 54).

De hecho, cuando más adelante se haga referencia al acceso, se extenderá a todo material relacionado que los archivos poseen alrededor del cine. En una edición especial del Journal of Film Preservation, compilado por Sabine Lenk (1997), del Royal Film Archive of Belgium, se menciona que este 'repertorio' está compuesto por:

- material fílmico (película de seguridad, material de nitrato, vídeos, etc.)

- recursos visuales (fotografías, posters, dibujos, placas autocromas, diapositivas, placas de linternas mágicas, etc.)

- publicaciones (libros, revistas, diarios, catálogos, folletos, etc.)

documentos no publicados (manuscritos, guiones técnicos, estudios, notas privadas, etc.)

recortes (reseñas cinematográficas, comunicados de prensa, publicidad, etc.)

- registros sonoros (grabaciones, cintas, discos compactos, etc.)

artefactos (cámaras fotográficas y fílmicas, proyectores, accesorios, equipos y juguetes ópticos, materiales relacionados a la prehistoria del cine, etc.) (p. 8).

\subsubsection{Restauración, ética y autenticidad}

Dentro de lo que consideramos un solo proceso conocido como 'restauración', se enmarcan una serie de acciones de diversa índole. En primer lugar, nos enfrentamos a una fase de reparaciones básicas, enfocadas a tratar el material de manera más superficial. Estas consisten en limpiar la película, parcharla, quitar empalmes mal colocados o reemplazarlos, etc. Existe una fase de tratamiento fotoquímico, en el cual se requiere de un laboratorio especializado con las soluciones químicas que contribuyen a la estabilización del material. Y, finalmente, tenemos la restauración digital, que es la que se hace en una computadora, también con software especializado, que permite nivelar temas más puntuales como rayones, contraste, pérdida de color y otros asuntos que, en un laboratorio, serían imposibles tratar.

En cuanto a la restauración digital, salta la cuestión 'ética' de los restauradores, quienes poseen la responsabilidad de decidir sobre el material que están manipulando: 
¿en qué medida éste se mantiene 'fiel' al original? De acuerdo con el autor Mark-Paul Meyer (1998), no hay manera de saber cómo lucía la copia original en el momento de su estreno ni cuáles eran las características del granulado. Agrega que ni siquiera la supervivencia y la proyección actual de la copia original te aseguran que así fuese realmente vista en aquel entonces, pues la degradación y el deterioro químico y físico ha sido inevitable (p. 33). Entonces, ¿hasta qué punto se debe modificar o mejorar una imagen o un sonido?

Para Meyer, 'Queda claro que el concepto de 'original' en la restauración fílmica necesita mayor elaboración. En el caso de la restauración de la imagen y sonido, lo 'original' es por lo general aún un concepto abstracto, teórico” (p. 34). Según el autor, el valor de la 'autenticidad' es lo que debería ser rescatado. Ciertos daños producidos por el tiempo no deberían intentar eliminarse por completo, pues esos son también los rasgos de una experiencia estética particular. Por otro lado, resulta más conveniente el limitar la manipulación en aras de un trabajo más preciso de investigadores y restauradores en los años venideros (p. 35). La responsabilidad de los archivos es fundamental en la manera en que guían la labor del restaurador, quien, frente a las posibilidades infinitas que le ofrece una computadora, será quien decida sobre el futuro de la película. En ese sentido, Meyer enfatiza sobre la convergencia de diversas disciplinas para lograr la mayor autenticidad posible. Por ejemplo, menciona el caso de dos pinturas de Vermeer, cuya restauración estuvo a cargo de la galería Mauritshuis The Hague. Para esto, se convocaron tanto a restauradores, como especialistas en historia del arte, en química y en física. "Algunos museos, como The National Gallery of Art en Washington, tienen hasta su propio Departamento de Investigación Científica” (p. 36), agrega.

La FIAF cuenta con un Código de Ética a través del cual, entre otras cosas, promueve la responsabilidad de los archivos en transmitir su patrimonio "como la representación más fiel posible del trabajo de sus creadores” (FIAF, 1998, párr. 1). De manera puntual, sobre la restauración y los derechos de las colecciones, indican: “Cuando restauran materiales, los archivos solo procuran completar lo incompleto y eliminar los estragos del tiempo, el uso y la desinformación. No intentarán modificar ni distorsionar la naturaleza de los materiales originales ni las intenciones de sus creadores" (FIAF, 1998, sección Los derechos de las colecciones, párr. 5). 


\subsubsection{Acceso y puesta en valor}

De acuerdo con la FIAF, el acceso a las colecciones de un archivo se presenta bajo dos modalidades. La primera es el llamado acceso activo, el cual se hace efectivo cuando el archivo mismo expone su propio material. Digamos que éste 'saca' al público su colección. De manera directa, este es el trabajo de la programación. Michelle Aubert (1997), antiguo director de la FIAF, compara esta tarea con las exhibiciones públicas de los museos de arte. En el caso de una cinemateca, "La programación involucra presentar al público, de manera regular y dentro de un marco de trabajo selectivo y organizado, películas preservadas por el archivo (y frecuentemente también títulos no contenidos en las colecciones permanentes)" (p. 3). A esto habría que añadir la programación en línea; el poner a disposición de diversos usuarios el patrimonio a través de Internet. A nivel latinoamericano, este es el caso de Cineteca Online ${ }^{6}$, un portal de la Cineteca Nacional de Chile a través del cual se puede consultar y ver largometrajes, cortometrajes, reportajes y otros materiales audiovisuales de producción nacional.

La segunda modalidad es el acceso pasivo; cuando el archivo reacciona a las demandas del público. Se refiere al acceso solicitado por diferentes categorías de usuarios (por ejemplo, el que solicitan investigadores, universidades, festivales, estudiantes, etc.). Algunas filmotecas, como la de la Universidad Nacional Autónoma de México (UNAM), proveen un espacio dentro de sus instalaciones para que sus usuarios revisen el material que custodian. Esto es sobre todo necesario cuando, por temas legales, el material no puede ser exhibido de manera libre.

Queda bastante claro que el fin último de todo archivo fílmico es el de poner a disposición de sus usuarios las obras que preservan, de la forma en que esté bajo sus posibilidades legal, técnica y económicamente. Esta es la única manera en que, ya sea por fines educativos, de investigación o lúdicos, se le conceda valor al patrimonio. Sus agentes (instituciones y usuarios actuales) trabajan bajo una fuerza de cohesión que es el compromiso con la actividad. Esta serie de operaciones serían las promotoras de hacer llegar este conocimiento a futuros usuarios (Del Valle Gastaminza, 2013, p. 122). Para Torres Moya, de la Fundación Patrimonio Fílmico Colombiano, “la 'puesta en valor' de los archivos audiovisuales se basa en la idea de que aquellos registros y obras

\footnotetext{
${ }^{6}$ www.ccplm.cl/sitio/secciones/cineteca-nacional/cineteca-online/
} 
audiovisuales que no están disponibles para su difusión pierden valor" (como se citó en Wiener Fresco, 2015, p. 19).

Auber (1997) también señala que algunos de los obstáculos que enfrenta el acceso en los archivos fílmicos son las regulaciones sobre el derecho de autor, la demanda de mayores esfuerzos administrativos, técnicos y económicos y la carga adicional sobre un equipo de trabajo que es, de por sí, reducido para cumplir con el resto de las labores de una cinemateca (p. 4).

Los archivos desarrollan protocolos sobre el acceso: proponen una modalidad de catalogación, un sistema de priorización de atención de usuarios, consideraciones sobre los derechos de autor, entre otros. El tema de la autoría sobre la película varía de acuerdo con cada región. En algunos países, las películas pasarían, tras cincuenta a setenta años de la muerte del autor, al dominio público. En algunos otros, dicho periodo es más extenso o sujeto a otra clase de condiciones, no hay exigencias de depósitos legales (o cambian según la época) o la definición sobre la figura del 'autor' es más compleja. De igual forma, sucede también que quien deposita una película en un archivo no es, necesariamente, el propietario. Esto torna compleja la difusión del material en términos legales y, por tanto, el acceso es a veces restringido. 


\section{CAPÍTULO II: PANORAMA DE LA PRESERVACIÓN FÍLMICA EN PERÚ}

Un 'panorama' es un título un poco aventurado para este capítulo, que pretende, en el mejor de los casos, saber qué hubo en cuanto a iniciativas y, si éstas sobreviven, de qué manera lo hacen. Basta con recorrer un par de nombres e instituciones de manera muy breve para conocer en qué momento surgieron, cuáles fueron sus funciones, cómo operaron y a dónde llegaron. Se ha dividido el siguiente capítulo en un apartado sobre instituciones privadas y otro de instituciones públicas que, si bien no llevan el apelativo de archivos fílmicos, por ley o porque sus funciones colindaban con el almacenamiento de material audiovisual, llevan a cabo, en mayor o menor medida, acciones asociadas a estos.

Aquello servirá como una suerte de prefacio para el caso que deseamos conocer con mayor detalle. El año pasado, el Ministerio de Cultura convocó, por primera vez, un concurso de Proyectos de Preservación Audiovisual, en el cual hubo cinco ganadores y dos en lista de espera. Al conocerse el saldo disponible de los concursos del año, se declararon igualmente ganadores a los proyectos en lista de espera, entre los cuales estaba la digitalización de cinco películas de Francisco Lombardi.

El hecho de que películas que datan de décadas no tan lejanas se encontrasen participando, dieron cuenta del precario estado en que se encuentra nuestro cine y que urgían medidas para cuidarlo como patrimonio, si se pretende legar estas obras a un futuro lejano. El caso de las películas de Lombardi manifiesta muy bien el descuido que hubo entre los cineastas en aquella época, y que también hubo en el Estado mismo, por preservar lo que se hacía; y de igual forma muestra los vaivenes por los que pasaron estos rollos y las a veces travesías por las que se ha tenido que pasar para recuperarlas. Asimismo, pone sobre la mesa los esfuerzos personales por conservar un cine que se ubica ya en una línea de historia cinematográfica, por seguir distribuyéndola y de los esfuerzos del actual Ministerio de Cultura por hacer cumplir, aunque de manera muy tímida y débil aún —el monto asignado es muy bajo y todavía no contamos con una cinemateca nacional-, la Ley en cuanto a preservación audiovisual. 


\subsection{Repaso de archivos privados peruanos}

A lo largo del siglo pasado, surgieron una serie de iniciativas privadas para la creación de archivos fílmicos nacionales. Los representantes de estas instituciones, algunas más fugaces que otras, fueron Miguel Reynel Santillana (Cinemateca Universitaria), Francisco Adrianzén (Cinemateca de Lima), Isaac León Frías (Filmoteca de Lima), Norma Rivera (Filmoteca de Lima) e Irela Núñez del Pozo con Mario Lucioni (Archivo Peruano de Imagen y Sonido). ${ }^{7}$

\subsubsection{La Cinemateca Universitaria}

La primera iniciativa de una cinemateca en Perú surgió en 1965. Llamada Cinemateca Universitaria, fue fundada y dirigida por Miguel Reynel Santillana (19222005), quien fue Jefe de Extensión Cultural y Relaciones Públicas de la Universidad Agraria La Molina. Gracias a su labor, se rescataron y se exhibieron una serie de clásicos del cine del mundo. Henri Langlois y la Cinémathèque Française donaron inicialmente algunos títulos (De Cárdenas, 2014, p. 20). Aunque hoy este sea un hecho que quizá solo recuerden los que vivieron el alcance de una actividad de alrededor de quince años, su importancia se manifiesta en una mención en la lista mundial de cinematecas (al 31 de diciembre de 1982) en el libro Les cinémathèques de Freddy Buache y Raymond Borde, este último fundador de la conocida Cinemateca de Toulouse. Esto se debe también a que fue la primera cinemateca peruana admitida en la FIAF (Wiener Fresco, 2015, p. 57).

A fines de 2006, Walter Meza Medina, quien fue asistente de Reynel y curador del archivo, y el realizador Nelson García Miranda, elaboraron un inventario preliminar cuyo conteo fue de 164 títulos (75 en $35 \mathrm{~mm}, 51$ en $16 \mathrm{~mm}$ y 38 probables $^{8}$ ), entre los que se hallan películas extranjeras, sobre todo soviéticas. En cuanto a material peruano, probablemente se tenga una copia de Kukuli (Luis Figueroa, 1961) y de Intimidad en los parques, coproducción peruano-argentina de 1965 dirigida por Manuel Antín, además de

\footnotetext{
${ }^{7} \mathrm{Si}$ se desea complementar el conocimiento en cuanto a estas instituciones, se recomienda revisar el informe de Wiener Fresco o la tesis de Díaz Cervantes que se encuentra en la sección de referencias.

${ }^{8}$ Se refiere a títulos que probablemente hayan formado parte de la colección.
} 
algunos cortometrajes como Bombón Coronado campeón (Nelson García Miranda, 1974). Actualmente se desconoce el paradero de este archivo (Wiener Fresco, 2015, p. 59).

\subsubsection{La Cinemateca de Lima}

Entre 1980 y 1985, un entusiasta grupo del Cine Club Kunam, fundado por el realizador audiovisual Francisco Adrianzén, crea La Cinemateca de Lima. Esta iniciativa fue también impulsada por el uruguayo Walter Tournier, con quien Adrianzén pensó en formar un archivo con títulos latinoamericanos, especialmente de corte social y político. Varios otros cineastas se unieron a este grupo, como Nora de Izcue, quien fue su primera presidenta.

Durante cinco años, realizaron una serie de proyecciones en diversos cineclubes y organizaciones populares. Sin embargo, de acuerdo con Wiener Fresco (2015), “esta actividad llevó al inevitable conflicto entre los que priorizaban las exhibiciones, frente a quienes más bien apostaban al rescate y conservación del material audiovisual para las futuras generaciones" (p. 60). Para Francisco Adrianzén, los grandes esfuerzos económicos que demandaba el mantenimiento de la cinemateca, la cual no podía ser autofinanciada y requería incluso de aportes de los mismos miembros, fue un punto crucial para su disolución (Díaz Cervantes, 2014, p. 86).

Como cinemateca, en todo lo que se refiere a sus ejes, Adrianzén explica que estaba enfocada en almacenar y en difundir (a través de las mencionadas proyecciones descentralizadas). A pesar de la consciencia que se tenía sobre el valor de la preservación, lamentablemente no se contaba con un lugar condicionado que sirviera de depósito; ni con los instrumentos técnicos para llevar a cabo acciones de recuperación.

Debido a que EDUBANCO estaba pensando invertir en el Museo de Arte de Lima y que la Cinemateca de Lima solía realizar parte de sus actividades en dicho local, ya que no contaban con uno propio, el director de la institución, Alejandro Vasilaqui, los contacta para conversar sobre la iniciativa de formar la que sería la Filmoteca de Lima (Díaz Cervantes, 2014, p. 85). 


\subsubsection{Archivo Peruano de Imagen y Sonido (ARCHI)}

El Archivo Peruano de Imagen y Sonido (ARCHI) es una institución fundada en 1991 por la conservadora Irela Núñez del Pozo junto con el investigador Mario Lucioni y Hernando Luque, los tres egresados de la Universidad de Lima y quienes participaban en la revista de cine El Refugio (Díaz Cervantes, 2014, p. 91). Núñez del Pozo se autodefine a ella y a sus colegas como "egresados de la universidad" que buscaban "salvar el cine peruano" (Gabriel Quispe Medina, 2014), y ese es, más o menos, su enfoque en la actualidad, pues sólo preservan material producido en Perú.

Este grupo se formó a partir de un trabajo de catalogación e inventario de la colección de Noticiarios Peruanos de mediados del siglo XX con la que contaba la Biblioteca Nacional del Perú (Gabriel Quispe Medina, 2014). Se trataba de alrededor de dos mil rollos de película de nitrato. Parte de este material ha sido recientemente digitalizado (como un trabajo propio de la BNP, sin participación del ARCHI) y puesto al alcance de cualquier usuario a través de un portal web de la institución pública.

Como se menciona en su sitio web, el acervo del ARCHI nació a partir de la toma de conocimiento de "la existencia de un archivo importante que, ante el desinterés local, su productor quería vender al extranjero". Así, su fondo fílmico se enriqueció con otras "adquisiciones, donaciones y depósitos de cineastas peruanos y productoras de cine, algunos de ellos obligados a abandonar la actividad por la crisis económica y legal del sector".

La situación era tan convulsa en aquella época que Núñez del Pozo y Lucioni se vieron obligados a migrar para continuar con sus estudios y con sus labores en el ARCHI. Desde afuera, ambos continuaron recolectando filmes y realizando restauraciones gracias a diversos apoyos (Gabriel Quispe Medina, 2014). Especialmente Núñez del Pozo, quien estudió preservación, ha trabajado para la Cinemateca de Roma y ha colaborado también con la Filmoteca Española. Radica en Italia, donde trabaja en el ARCHI los fines de semana, pues en ese país sí hay laboratorios fílmicos y existe la posibilidad de obtener ayudas económicas. Ibermedia ${ }^{9}$ es uno de los incentivos que han ganado para restaurar

\footnotetext{
${ }^{9}$ Programa de estímulos económicos dirigido, sobre todo, a la coproducción de películas entre los veintiún países que forman parte de la comunidad (entre ellos se encuentran tanto Perú como Italia).
} 
un documental del año 1929, llamado Excursión de los congresistas a la montaña, hecho en Chanchamayo y Cusco.

Lo que el ARCHI realiza, además de un trabajo profesional de restauración, es la identificación de películas. Cada filmación tiene una historia detrás, por lo que se investiga sobre su contenido, su procedencia, su realización y otros datos similares. En la colección del ARCHI, figuran documentales como Captura del bandolero Andrés Ramos $\left(\right.$ Francisco Diumenjo, ca. 1933) ${ }^{10}$, también una ficción cuyo título asignado es Comedia del Taller Garland (Guillermo Garland Higginson, 1927) ${ }^{11}$ y hasta se encuentra un fragmento de la película peruana Gallo de mi galpón (Sigifredo Salas, 1938) ${ }^{12}$ en la que Jesús Vásquez canta El plebeyo, que se extrajo del documental Los Pioneros (Jorge Reyes, 1975) ${ }^{13}$. La calidad del vídeo se debe a que cuentan con el negativo original del filme.

El ARCHI conserva alrededor de cuatro mil rollos de película de producción peruana y, aunque su actividad es ahora muy esporádica, aún operan para la adquisición, conservación e investigación (Díaz Cervantes, 2014, p. 91).

\subsubsection{La Filmoteca de Lima y la Filmoteca PUCP}

El impulso que pervive es el inicialmente liderado por la Fundación BBVA Banco Continental, bajo el antiguo programa Edubanco, el cual creó en 1986 la Filmoteca de Lima Museo de Arte Edubanco, la cual posteriormente pasaría a manos de la PUCP. Entre 1986 y 2001, dicha institución privada fue dirigida por Isaac León Frías. Entre sus misiones, se encontraban la adquisición de filmes y la constitución de un espacio alternativo de proyección. Además de películas, comenzaron también a conservar otros materiales asociados al proceso de producción y distribución como afiches, guiones, revistas y libros de cine. Su colección estaba compuesta por alrededor de tres mil

\footnotetext{
${ }^{10} \mathrm{Se}$ puede ver en https://www.youtube.com/watch?v=gDGBLrkVeKo

${ }^{11}$ Se pude ver en https://www.youtube.com/watch?v=X5aXTbbZodY

${ }^{12}$ Se puede ver un avance de la restauración en https://youtu.be/vNFYx3tCQ6c

${ }^{13}$ Se trata de un cortometraje documental en blanco y negro, de doce minutos, filmado en $35 \mathrm{~mm}$. Fue producido por Eduardo Tellería Pantoja. Trata sobre el cine peruano de los años treinta y cuarenta; y en él se encuentran entrevistas a personajes como Manuel Trullen, Eduardo Tellería y Pedro Valdivieso. El primero fue socio de Amauta Films, productora de la película Gallo de mi galpón.
} 
películas extranjeras y varios títulos peruanos, entre los que destacan largometrajes y cortometrajes producidos desde los setenta (por ejemplo, la obra del grupo Chaski y del mismo Lombardi). De fechas anteriores, contaban con noticieros de los años cincuenta.

Entre el equipo técnico, se hallaban Norma Rivera - quien actualmente es coordinadora de la Filmoteca PUCP —, la restauradora Irela Núñez del Pozo — ahora del ARCHI-, Gisela Hurtado y dos personas que estaban a cargo de la reparación de películas, quienes además aprendían la labor a través de talleres, pues no se contaba con programas técnicos o profesionales de conservación audiovisual en Perú ${ }^{14}$. Estas reparaciones eran mínimas, en primer lugar, por la falta de especialización, y en segundo término, debido a la inexistencia de laboratorios en nuestro país. Con lo que sí contaba la vieja Filmoteca de Lima era con bodegas de almacenamiento en el Museo de Arte (Díaz Cervantes, 2014, pp. 94-95).

En la actualidad, la Filmoteca PUCP tiene su sede en Magdalena y cuenta con un pequeño equipo. María Ruiz Vivanco fue productora y post productora de diversos cortometrajes y largometrajes peruanos, sobre todo durante la época de la Ley №19327. Esto le permitió tener un acercamiento directo a materiales fotoquímicos. En la actualidad, es la encargada de la revisión y reparación del material que resguardan. Trabaja en la Filmoteca PUCP recibiendo, investigando, catalogando y restaurando películas.

En cuanto a la adquisición, la Filmoteca PUCP obtiene películas bajo diversas modalidades. Algunas veces mediante búsquedas; otras por donaciones. Los rollos son recibidos en muy diversos estados, algunos ya en plena cristalización o licuación. El equipo de trabajo de la filmoteca registra todo lo recibido por fotografías y le asignan un

\footnotetext{
${ }^{14}$ Actualmente tampoco se cuenta con un plan académico enfocado en la conservación audiovisual. De hecho, en el área de la conservación, hasta hace algún tiempo quizá era sólo la Escuela Nacional de Bellas Artes la encargada en este tipo de formación, aunque centrada en arte pictórico y escultórico. Desde el 2011 opera la Escuela Profesional de Conservación y Restauración en la Universidad Nacional Mayor de San Marcos que, si bien se enfoca en arquitectura, textiles, cerámica y pintura, el currículo evidencia un alto grado de conocimiento de técnicas generales de conservación, además de un electivo en conservación fotográfica y un par de cursos y talleres obligatorios que también abordan el tratamiento de este tipo de documento.
} 
número con el cual ingresan al archivo (M. Ruiz Vivanco, comunicación personal, 26 de noviembre de 2018) ${ }^{15}$.

Para conservarlas y almacenarlas, trabajan bajo un sistema de colores con el cual determinan el nivel de deterioro de la película. Estos niveles van de 0-3, entre los cuales se consideran las cifras medias $(0 ; 0,5 ; 1 ; 1,5$ y así). Las películas consideradas en buen estado (0 y 0,5) se depositan en una misma habitación. Aquellas en estados 1 y 1,5 van a otra. Mientras que las que ya se encuentran en un nivel de deterioro muy alto se almacenan en un depósito aparte. Esto da un total de tres bóvedas climatizadas. Los tratamientos para cada una de éstas resultan diversos, de acuerdo con el tipo de soporte, gelatina, cualidades de color y, por supuesto, nivel de deterioro.

En lo que respecta a la restauración, manejan tres conceptos: física, química y digital. En nuestro país sólo es posible llevar a cabo pequeñas reparaciones físicas (limpiado del rollo y extracción y sustitución de empalmes). Esto se debe a que, para lograr la restauración química y la digital, son necesarios un laboratorio de películas (que no existe y nunca ha existido en nuestro país) y un escáner y equipos especializados (altamente costosos para cualquier institución), respectivamente. Lo que se lleva a cabo en la Filmoteca PUCP es un arduo trabajo de revisión del material que ingresa, de catalogación y de inspección. Examinando fotogramas con una lupa, han reconocido una gran cantidad de material valioso que esperan, en algún momento, pueda exhibirse y ser de acceso público.

Las restauraciones se han ejecutado en alianza y de la mano con otras instituciones ${ }^{16}$. Entre las obras restauradas por la Filmoteca PUCP, Wiener Fresco menciona De carne somos (Sigifredo Salas, 1938) de la productora Amauta Films; documentales y noticieros cinematográficos del español Manuel Trullen y Taita Cristo (Guillermo Fernández Jurado, 1967), “cuya restauración fotoquímica se realizó en la Filmoteca de la UNAM a partir de dos copias en positivo, donadas por el señor Julio Gutiérrez y bajo el auspicio del doctor Fausto Viale Salazar" (Wiener Fresco, 2015, p. 64). A estas habría que agregar Yo perdí mi corazón en Lima (Alberto Santana, 1933),

\footnotetext{
15 Toda referencia ingresada desde aquí sobre la dinámica de la Filmoteca PUCP se debe a una conversación que se tuvo con Ruiz Vivanco el 26 de noviembre de 2018, salvo por el último párrafo, cuyas citas se detallan.

${ }^{16}$ Por ejemplo, en el sitio web de la Filmoteca PUCP, se explica que la película De carne somos fue restaurada gracias al auspicio del Proyecto de Conservación del Patrimonio Audiovisual de América Latina, patrocinado por la Agencia Española de Cooperación Internacional para el Desarrollo (AECID) e Ibermedia, junto con la Filmoteca de la UNAM.
} 
recuperada en los noventa y también restaurada en laboratorios mexicanos; así como Los conflictos de Cordero (Sigifredo Salas, 1940) - una más de Amauta Films-, Dos caminos (Salvador Akoskin, 1972), cortometrajes de Antonio Wong Rengifo' ${ }^{17}$ y Cuentos Inmorales (José Carlos Huayhuaca, Augusto Tamayo San Román, José Luis Flores Guerra, Francisco Lombardi, 1978) (N. Rivera Valdivia, comunicación personal, 09 de julio de 2019).

\subsection{Instituciones públicas en el Perú}

En Perú, en términos audiovisuales, son cuatro las instituciones públicas que conservan patrimonio, aunque no funcionen estrictamente como archivos fílmicos: el Archivo General de la Nación (AGN), la Biblioteca Nacional del Perú (BNP), la Dirección del Audiovisual, la Fonografía y los Nuevos Medios (DAFO) y el Instituto Nacional de Radio y Televisión del Perú (IRTP).

Tabla 2.1

Composición de los acervos de la AGN, la BNP, la DAFO y el IRTP al 2018.

\begin{tabular}{|c|c|c|c|c|}
\hline \multirow{2}{*}{$\begin{array}{l}\text { Institución } \\
\text { pública }\end{array}$} & \multirow{2}{*}{$\begin{array}{c}\text { Total de materiales } \\
\text { audiovisuales }\end{array}$} & \multicolumn{3}{|c|}{ Tipos de formatos } \\
\hline & & Electromagnético & Fotoquímico & Digital \\
\hline AGN & 316 & 2 & $v$ & \\
\hline BNP & 24647 & 8 (6 son solo audio) & 1 & $\begin{array}{l}5 \text { (1 es solo } \\
\text { audio) }\end{array}$ \\
\hline DAFO & 1314 & 2 & 2 & 6 \\
\hline IRTP & 156434 & $\begin{array}{c}18 \text { (9 son solo } \\
\text { audio) }\end{array}$ & 2 & $\begin{array}{l}2 \text { (1 es solo } \\
\text { audio) }\end{array}$ \\
\hline
\end{tabular}

${ }^{17}$ Antonio Wong Rengifo (1910-1965) fue un fotógrafo y director de cine iquiteño, pionero en su región. Se cuenta con una serie de siete cortometrajes suyos acerca de la cotidianeidad en Iquitos conocida como la Revista loretana, la cual registró hasta 1934 con una máquina De Vry (Bedoya, 1997, p. 95). Estas cámaras fueron muy populares en el uso de noticieros cinematográficos, debido a que la compañía desarrolló un modelo compacto de 35mm (Varios, 2012, p. 163). También se cuenta con un largometraje de Wong, Bajo el sol de Loreto (1936), rodado ya con una cámara Pathé, que, al momento, no ha sido restaurado. 
Fuente: Tabla de elaboración propia a partir de los datos brindados en el encuentro "La memoria audiovisual como política pública" organizado por el Ministerio de Cultura del Perú y llevado a cabo en la sala de cine Armando Robles Godoy el 01 de octubre de 2018. Participaron Tzutzumatzin Soto Cortés (directora del Departamento de Acervo Videográfico de la Cineteca Nacional de México), Hugo Coya Honores (presidente ejecutivo del IRTP) y Pierre Emile Vandoorne Romero (director de la DAFO).

Aunque el IRTP se erige como el máximo depósito de material audiovisual (tabla 2.1), éste es predominantemente electromagnético y, claro está, de producción televisiva o radial. En cuanto al AGN, cuenta con soportes sólo electromagnéticos, pues su labor está enfocada en lo bibliográfico.

La BNP realiza, tanto también porque la legislación así lo determina, acciones más extensas y activas de preservación. Su archivo, aunque bibliográfico en su mayoría, incluye también otros materiales como pinturas, acuarelas y fotografías. Algunos de estos trabajos se han hecho visibles al público a través de exposiciones temporales en la sede San Borja de la BNP. Por motivo del 194 aniversario de la institución, se inauguró, el 28 de agosto de 2015, la muestra 'Retratando Lima', una exposición fotográfica del archivo Courret Hnos. (1863-1935).

Otra de las iniciativas que se tomaron fue la creación de la plataforma Biblioteca Digital (BD), con la cual se accede de manera gratuita desde cualquier dispositivo electrónico, al patrimonio que custodian. Entre ellos se encuentran mapas, planos, folletos, libros, documentos registrados en la Memoria del Mundo de la UNESCO y un catálogo multimedia con 382 imágenes (colecciones de Sánchez Cerro, Courret, Luis Ugarte, Garreaud, entre otros) y 627 clips de tele cine (una serie de noticiarios peruanos de los años cuarenta en blanco y negro) cuyo soporte original es el nitrato de celulosa ${ }^{18}$. Estos son los noticiarios que empezó a catalogar el ARCHI en 1991. Lamentablemente, como Núñez del Pozo cuenta, el avance era muy lento debido a que no existían las condiciones adecuadas. La digitalización ha sido ya un trabajo posterior de la misma BNP. Como indican en su canal de Youtube, el proceso de digitalización audiovisual ${ }^{19}$ es llevado a cabo gracias a equipos especializados de conversión que fueron donados por el Gobierno de Japón.

Respecto al acervo de la DAFO, lo que corresponde a material fotoquímico, por condiciones de climatización, es custodiado por la Filmoteca PUCP. En total son 314

\footnotetext{
${ }^{18}$ Material consultable en http://bdigital.bnp.gob.pe/Bvirtual/Home

19 Trabajan con materiales diversos como película de 35mm, Betamax, VHS, DVD, discos de carbón, vinilo, cintas de audio a carrete abierto y casetes. Mayor información se puede consultar en: https://youtu.be/tJdxIlYigxk
} 
ítems en formatos fotoquímicos. Los formatos digitales, principalmente discos duros con formatos Digital Cinema Package (Paquete Digital para Cine o DCP, por sus siglas en inglés) son custodiados por la misma DAFO en la sede central del Ministerio de Cultura. 


\subsection{El caso de las películas de Lombardi}

\subsubsection{Introducción}

El 28 de marzo de 1972 fue publicada la Ley Nº19327, Ley de Fomento de la Industria Cinematográfica, durante el gobierno militar presidido por el General Juan Velasco Alvarado. Como bien condensa Wiener Fresco en el prólogo del libro Cuando el cine era una fiesta de García Miranda (2013):

"Los principales beneficios de esta legislación fue la creación del sistema de exhibición obligatoria para las películas nacionales de largo y cortometraje, calificadas por la Comisión de Promoción Cinematográfica -COPROCI, dependencia formada por representantes de diversas instancias del Estado. El otro incentivo fue tributario, con la deducción en todo o en parte del impuesto de destino municipal a las entradas de cine, en beneficio de las empresas productoras peruanas, así como exoneraciones para la importación y exportación de equipos y copias de películas” (posición 204) ${ }^{20}$.

Francisco Lombardi fue uno de esos cineastas, junto con Nora de Izcue, Aldo Salvini, Augusto Tamayo, entre otros, que motivaron su producción cinematográfica gracias a la nueva legislación. A ellos se suman varios técnicos que se formaron bajo esta práctica. Ya en 1974, Francisco Lombardi había trabajado como director en los cortometrajes documentales Visión de José María Eguren y Ritual de flores, ambos producidos por Inca Fims S.A. Dicha productora era dirigida por José Zavala Rey de Castro, Francisco Lombardi Oyarzu, Emilio Moscoso Manrique y José Luis FloresGuerra Luque, cada uno de los cuales se desempeñó en un área distinta en cada producción (García Miranda, 2013, posición 22539).

Sin embargo, no es hasta 1977 que filman su primer largometraje de ficción, Muerte al amanecer, que trata el caso del conocido como 'El Monstruo de Armendáriz', una ejecución injusta a un hombre culpado por homicidio. Esta película le valió una mención especial en el Festival Internacional de Cine de Locarno y otros reconocimientos en Cartagena y La Habana. Desde ahí, Lombardi arrancó una carrera constante en la

\footnotetext{
${ }^{20}$ Cuando el cine era una fiesta es un libro electrónico disponible en Amazon. La ubicación de los textos no se controla según números de página, sino por posiciones.
} 
dirección cinematográfica, que posteriormente, se volvió más intermitente. La Ley No19327 fue derogada el 23 de octubre de 1994, dos años después del inicio del gobierno de Alberto Fujimori y, por ella, entró en vigor la Ley N²6370, Ley de cinematografía peruana, la cual supuso el fin de la exhibición obligatoria y otra serie de estímulos fiscales. Entre los cambios más relevantes, estuvo la conformación del Consejo Nacional de Cinematografía (CONACINE), el cual estaba a cargo de los fondos ahora concursables. Actualmente esta es la labor que vendría a desempeñar la DAFO. A diferencia de la anterior ley, esta sí incluye entre sus objetivos la preservación del patrimonio audiovisual, a través del establecimiento de filmotecas y otros centros especializados, hecho que, hasta el día de hoy, no se ha cumplido.

Las películas que se tratan en el presente documento fueron filmadas entre 1977 y el $2000^{21}$ y corresponden a filmografía en material analógico. Todas fueron grabadas en $35 \mathrm{~mm}$, salvo por Muerte de un magnate, cuyo soporte era de $16 \mathrm{~mm}$, y de la cual posteriormente se realizó un blowup en $35 \mathrm{~mm}^{22}$. Estas películas eran de acetato a color, filmadas en cámaras propias de la época. Por ejemplo, La ciudad y los perros y La boca del lobo se rodaron en unas ARRI; la primera en una $2 \mathrm{C}$ y la segunda en el modelo BL (E. Moscoso Manrique, comunicación personal, 25 de febrero de 2019).

Un óptimo proyecto de recuperación con material de ese tipo, como se ha venido revisando en el marco teórico, involucraría el almacenamiento adecuado de los negativos para desacelerar su degradación, así como un tratamiento del material para restaurarlo, en caso sea necesario. Se contaría también con los positivos y con copias de exhibición, que bien podrían ser digitales. También estaría involucrada la conservación de materiales asociados como afiches, notas de prensa, reseñas en diarios, entrevistas relacionadas a su producción, entre otros. Y todo esto enfocado en la revalorización del patrimonio y en su acceso desde la ciudadanía.

Pero a este punto convergen una serie de vicisitudes que hacen necesaria la reformulación de un plan demás ambicioso. Como explicaremos más adelante, el primer paso, el de ubicar los negativos, es ya una empresa difícil. Además, la falta de una

\footnotetext{
${ }^{21}$ Las fichas de estas películas con la información técnica, sinopsis y lista de reconocimientos se encuentran en el anexo de esta investigación.

${ }^{22}$ El blowup consiste en la ampliación de una cinta. En este caso, de un negativo en $16 \mathrm{~mm}$ a uno en $35 \mathrm{~mm}$. La gran desventaja de este procedimiento es que, dado que un cuadro de $16 \mathrm{~mm}$ debe multiplicar su tamaño original, lo mismo sucede con el grano, el cual se hace más visible para el ojo humano. Para mantener el grano lo más fino posible, se recomienda usar una película de ISO 100 y una exposición mayor. Fuente: https://www.questia.com/magazine/1P3-1298978981/shooting-16mm-for-blowup-to-35mm-film
} 
cineteca nacional, o similar, torna complicado el hecho de encontrar un espacio correcto para almacenarlas. Asimismo, al no haber proyectos directamente impulsados por el Estado, dificulta el tema presupuestario y de rigurosidad técnica de las propuestas. En el caso particular de Francisco Lombardi, lo que se ha presentado es un proyecto de digitalización de las mejores copias en material fílmico que ha logrado ubicar de La boca del lobo (1988), Caídos del cielo (1990), Bajo la piel (1996), Tinta roja (2000) y Ojos que no ven (2003) (E. Moscoso Manrique, comunicación personal, 25 de febrero de 2019). Isaac León Frías es una de las personas que ha comentado sobre las falencias del nuevo concurso, al indicar que un proyecto de preservación no puede limitarse a la digitalización, pues la prioridad debe ser la recuperación y restauración del material fílmico. Aquel otro proceso sería posterior, en tanto es importante para dar a conocer las obras (León Frías, 2019, párr. 2).

\subsubsection{Antecedentes y retos}

La razón por la que ubicar las copias es un problema, se remonta a los años en que estas películas fueron producidas, pues, como el mismo Lombardi declara, hubo mucho descuido personal y una nula preocupación por conservar los negativos (F. Lombardi Oyarzu, comunicación personal, 15 de mayo de 2019) ${ }^{23}$. Estos materiales originales se quedaron en diversas partes fuera de Perú, en los laboratorios en que fueron procesados, lo cual dependió del convenio de coproducción o al lugar donde, por temas económicos o logísticos, convenía que fuese tratado el material. Muchos laboratorios desaparecieron, sin dejar rastro sobre sus archivos; otros sufrieron por incendios. Si los negativos no se hallan, entonces se recurre a la búsqueda de positivos en estados aceptables, los cuales pueden estar también en los países donde se exhibieron las películas, si es que se contó con distribución internacional. Sin embargo, son tantos los años que han pasado que rastrear paraderos no es tarea sencilla.

Tal vez esto no hubiese sucedido si se hubiese contado con una institución que, más allá de preservar debidamente las películas, alertase sobre temas relacionados a la

23 Toda información expuesta en este y los siguientes subcapítulos fue otorgada por Lombardi en una entrevista que se llevó a cabo el 15 de mayo de 2019 en Miraflores, salvo los casos donde se indique otra fuente. 
conservación en el cine. En el circuito, el foco para los cineastas y demás interesados era (y es) producir. Con directores como Lombardi, quienes hacían películas con cierta continuidad, apenas un proyecto era culminado, se pensaba en el próximo. La película anterior era un tema del pasado y no una reescritura constante de la historia y de la memoria. Menguaba consciencia sobre la pérdida que significaría para futuras generaciones.

Si ahora surgen intentos por recuperar y preservar, por lo menos, sus películas más recientes, se debe a una preocupación personal de no dejar nada y a los impulsos que el nuevo concurso sobre Preservación Audiovisual del Ministerio de Cultura ha despertado. A ello, se suman demandas técnicas de las pequeñas ventas a canales de televisión que transmiten películas antiguas. Estos solicitan un nivel de calidad de imagen, sobre todo ahora en que los sistemas caseros o de streaming son reproducidos en pantallas grandes de mayor resolución, por lo que contar con el material digitalizado y en óptimo estado es indispensable.

Desde el punto de vista legal, significó un gran error el no contar con una ley de depósito para las películas en nuestro país. Si bien se creó la COPROCI para regular ciertas disposiciones de la Ley $\mathrm{N}^{\circ} 19327$, no hay en ningún momento mención sobre archivos o depósitos de películas. Su preocupación fue la de incentivar la producción nacional, a través de exoneraciones tributarias, y la proyección de esta, mediante la exhibición obligatoria. Existe una mención sobre depósito de películas cinematográficas en la Ley №26905, Ley de Depósito Legal en la Biblioteca Nacional del Perú, promulgada en 1997 y aún vigente, aunque no regulada. Es a partir de la conformación del CONACINE que los proyectos ganadores de los fondos concursables se ven obligados a entregar una copia final de la película a la mencionada institución (rollos que actualmente resguarda la Filmoteca PUCP), y lo mismo sucede con la DAFO, en cuyas Actas de Compromiso contemplan ya no la entrega de copias en $35 \mathrm{~mm}$, sino la cesión de una copia en DCP, al menos en el caso de largometrajes.

Los gastos que supone la restauración de una película en celuloide o acetato son muy elevados, como lo mencionamos en el apartado sobre los ejes de un archivo fílmico. Hasta hace unos años, la digitalización era también un proceso de ingente gasto que, con 
el tiempo y el aumento de la demanda, se ha tornado asequible ${ }^{24}$. Sin embargo, esto sólo resuelve parcialmente el problema de la preservación, pues deja pendiente el tema de los negativos.

Actualmente, se encuentran DVDs licenciados de la filmografía de Lombardi, los cuales son comercializados por Play Music mediante su marca Butaca Perú, pues cuentan con la exclusividad de venta de dichos filmes. Sin embargo, estas son copias de los materiales que se han podido encontrar; se trata, mayormente, de reproducciones secundarias de otro material que no estaba en la mejor calidad, pero que pertenecían al archivo que Lombardi consiguió recolectar. El director espera contar con material de mayor resolución para continuar la distribución a través de esta empresa y poner fuera de circulación las viejas copias que no reproducen de manera fiel las cualidades originales de las películas.

\subsubsection{Repaso cronológico de la ubicación de las películas}

Muerte al amanecer (1977), el primer largometraje de Francisco Lombardi, fue filmado en coproducción con Cine Films 71 C.A., de Venezuela, por lo cual los negativos se procesaron en el laboratorio Bolívar Films, en Caracas. Sin embargo, surgieron discrepancias entre los productores, quienes no se ponían de acuerdo respecto con los réditos. "La película había tenido un enorme éxito en Perú, pero no había tenido ningún éxito en Venezuela, lo cual es lógico para una película que toma un tema peruano y que tenía pocas referencias para el mercado venezolano”, explica Lombardi. El productor venezolano, Pedro Fuenmayor, no estaba de acuerdo con el pacto de mantener las ganancias en el país en el que se generaron. Lombardi nunca tuvo acceso al negativo debido a esta disputa y éste se quedó, supuestamente, en el Laboratorio Bolívar. El

${ }^{24}$ Al respecto, Lombardi comenta que, por un contacto de Technicolor de Canadá, que es donde se reveló y procesó Pantaleón y las visitadoras (1999), se enteraron que generar una copia en HD de dicha película costaba US\$40.000. Unos años más tarde, José Luis Flores Guerra, el fotógrafo de La ciudad y los perros, quien tenía vínculos con personal de Cinecolor Lab, en Argentina, consiguió una transferencia en HD de esa película por US\$3.000. En España, donde están todas las películas que fueron realizadas en coproducción y que corresponden a algunas de las más entrañables para Lombardi (La boca del lobo, Caídos del cielo, Bajo la piel, Ojos que no ven, Tinta roja), los laboratorios siguen siendo más costosos. Hoy en día le fue posible conseguir la digitalización en $4 \mathrm{~K}$ de algunas de sus películas por alrededor de US\$3.500 cada una. 
director mantiene la idea de recurrir a los vínculos de la Filmoteca PUCP con sus pares en Latinoamérica para poder establecer algún contacto que les permita conocer el paradero del negativo, que quizá ya no se encuentre en los depósitos de Bolívar Films, sino en la Cinemateca Nacional de Venezuela o en algún otro lugar de aquel país. Hasta el momento, no se conoce el estado en que se encuentra o si es que aún se conserva.

La siguiente película, Los amigos (1978), uno de los segmentos del largometraje Cuentos Inmorales, se perdió por razones muy distintas. Un distribuidor que residía en Los Ángeles compró los derechos para exhibir la película en alguna zona latina de Estados Unidos. Los negativos le fueron entregados para que realice las copias, pero la compañía a la que pertenecía esta persona desapareció. A pesar de los esfuerzos de Lombardi y de su equipo, no tienen rastro del negativo. La película se puede ver aún por un DVD de calidad baja. Lo que se conserva es una copia en $35 \mathrm{~mm}$ que la Filmoteca PUCP está tratando de recuperar en México, con la Cinemateca de la UNAM, con la cual ya ha trabajado para otras restauraciones.

En cuanto a este proyecto, existe un pequeño avance que se tuvo la oportunidad de ver en la Filmoteca PUCP. Se trata de una copia que cuenta con una serie de defectos propios del paso de los años, lo cual incluye una pérdida considerable de tonalidades que ha vuelto algo mono cromática la película. La restauración y digitalización están enfocadas en recuperar, de la manera más fiel posible, los colores originales. Esto se debe también a que se trataba de una copia de exhibición, la cual no tiene la misma calidad que el negativo. Asimismo, el sistema de distribución en Perú hacía que los rollos circulasen muchísimo y que el desgaste que se produce por el arrastre de la película al ser exhibida, fuese de mayor magnitud. Como nos comenta el director:

En esa época, las películas se exhibían en muchos cines con la misma copia, con el sistema de las motos. Las motos transportaban de un cine a otro las latas. Y todo el día estaban en ese plan. A la semana, esas copias estaban ya en mal estado. Y mis películas que, en esa época, tenían mucho éxito, en cuatro o cinco semanas las copias eran ya inservibles, llenas de rayas, cortadas. La copia que tiene la Filmoteca PUCP de Cuentos inmorales es un poco de eso; una de las pocas copias que quedaron (F. Lombardi Oyarzu, comunicación personal, 15 de mayo de 2019).

Salvo cines en los que no había canje, como podía suceder con El Pacífico, aún si la película permanecía durante semanas en cartelera, no se maltrataba tanto. También influyó el manejo de los proyeccionistas, quienes cortaban las películas de manera 
descuidada para facilitar el armado del rollo. Estas quedaban en tan mal estado, que ya no era siquiera factible conservar las latas. Es muy probable que las productoras hayan guardado copias que devolvían los cines luego de cumplirse el ciclo de proyección. Sin embargo, la empresa Inca Films S.A., que fue la que produjo las películas de Lombardi en aquella época, pasó por diferentes etapas y locales, hasta que quebró alrededor del año 2000. Fue ahí cuando se perdió todo.

En el caso de Muerte de un magnate (1980), el procesamiento se hizo en DuArt, en Nueva York, donde también se realizó el blowup. El negativo de esta película se ha perdido también, aunque circula un DVD, que es una suerte de 'edición de salvación' de la empresa Play Music, quienes también distribuyen Muerte al amanecer. Probablemente, como ha sucedido con los filmes de Armando Robles Godoy, sea ésta una transferencia de un VHS o un formato similar.

Al respecto, Emilio Moscoso cuenta que fue él el encargado del ciclo inaugural de la sala Armando Robles Godoy del Ministerio de Cultura y que el único lugar en el que pudo encontrar copias fue en Polvos Azules 25 . "En vida, Robles Godoy mencionaba que los negativos de sus películas ya no existían; que se habían perdido. La piratería ha servido como una suerte de 'salvavidas'. Al menos tenemos la posibilidad de que todavía exista su obra, a pesar de que no sea en circuito oficial" (E. Moscoso Manrique, comunicación personal, 25 de febrero de 2019). El asunto de la piratería, aunque polémico, indudablemente ha sido, en este caso, el 'aliado ilegal' de la preservación y distribución de algunas películas. A veces, se ha convertido en nuestro país en el único medio de disfrutar de algunas obras.

Maruja en el infierno (1983) es una película que, en palabras de Lombardi, gozó de mucha suerte. Hace unos ocho o diez años, cuando nació su preocupación por recuperar sus películas e inició la búsqueda de materiales, no daba con el paradero de Maruja en el infierno. El corte del negativo se había realizado en los Laboratorios Alex, en Buenos Aires, el cual quebró y cerró en $1995^{26}$. Cuando depositaron el archivo en una casa antigua, un incidente dañó buena parte de los rollos. Sin embargo, la película logró ser ubicada y llevada a Cinecolor Argentina, donde descubrieron que, milagrosamente,

\footnotetext{
${ }^{25}$ Polvos Azules es un popular centro comercial ubicado en el distrito limeño de La Victoria conocido por ofrecer mercadería ilegal y productos falsificados.

${ }^{26}$ Laboratorios Alex pasó por una serie de incidentes, los cuales abarcan un incendio en 1969 y el robo de 300 negativos de imágenes en 1990 (España, 1998, párr. 3).
} 
los negativos estaban en buen estado. Lombardi planea presentar este año el proyecto de digitalización de Maruja en el infierno al Ministerio de Cultura, ya que actualmente sólo se cuenta con una copia en digital de calidad media. Por el momento, el negativo se conserva en los depósitos de Cinecolor. Cabe agregar que esta compañía ya no ofrece sus servicios de revelado y copiado de material fílmico de 16 y 35 milímetros; en el 2016 cerró Cinecolor Lab, creado en 1980 por Abraham Kakovich con técnicos que venían de los laboratorios Alex, lo cual abrió un debate en Argentina sobre la preservación (Bilik, 2016, párr. 5).

Luego está La ciudad y los perros (1985), cuya post producción se realizó en España. Esta película tuvo una distribución muy amplia en diversas partes del mundo, por lo que continuamente se tenían que sacar copias. De ahí que fuese el negativo llevado a Argentina, a Cinecolor Lab, donde resultaba más económico realizar este procedimiento. La película aún se halla en los almacenes de dicha empresa. Se hizo una digitalización en HD, del cual se cuenta con un DCP. Este proceso fue financiado por el propio Lombardi, para quien sería ideal tener una digitalización en 4K.

\section{La boca del lobo (1988), Caídos del cielo (1990), Bajo la piel (1996) y Tinta roja}

(2000) fueron realizadas en coproducción con la empresa Tornasol Films, de Gerardo Herrero, basada en Madrid. De manera obligatoria, los negativos fueron depositados en la Filmoteca Española. Para distribución, sólo existen DVDs de calidad bastante mala que se hicieron a partir de otras copias. Francisco Lombardi entró en conversaciones con el coproductor español para financiar, a medias, la digitalización de aquellas películas. Tras las negativas que recibió, surgió el concurso de la DAFO, al cual recurrió Lombardi. Para la ejecución del proyecto, con el que ganó el año pasado el incentivo a la Preservación Audiovisual, viajó a inicios de este año a Madrid a gestionar con la Filmoteca Española la digitalización, en un laboratorio español, a $4 \mathrm{~K}$ de los filmes mencionados. Dentro del encargo, estuvo también Ojos que no ven (2003) que, si bien ya no formaría parte de la investigación porque corresponde a su filmografía digital, pertenece a un caso particular que se explicará más adelante.

Aquel material digital fue traído a Perú para la colorización en Guarango ${ }^{27}$, tarea que ya fue culminada. Los negativos continuarán conservándose en la Filmoteca

\footnotetext{
${ }^{27}$ Guarango Cine y Video es una empresa peruana dedicada a la producción audiovisual. Es liderada por los hermanos Ricardo y Tito Cabellos. También ofrecen servicios de postproducción enfocados en digitalizaciones, generación de DCP, colorización, entre otros.
} 
Española, que es adonde pertenecen. Mientras que las versiones digitales servirán para hacer copias en BluRay, DCP y DVD para exhibiciones culturales, rubro en el que más se solicitan. El director conservará también un DCP de cada película, entregará uno a la DAFO (pues es una de las obligaciones indicadas en el Acta de Compromiso de los proyectos ganadores) y legará otro a la filmoteca PUCP.

En el lapso entre Caídos del cielo y Bajo la piel, Lombardi realizó Sin compasión (1994), coproducción entre Perú, México y Francia. Debido a la participación, aunque minoritaria, de una empresa mexicana, existe un inter negativo ${ }^{28}$ de $35 \mathrm{~mm}$ en un laboratorio de aquel país. Luego, entre Bajo la piel y Tinta roja, se estrenaron dos películas de producción íntegramente peruana: No se lo digas a nadie (1998) y Pantaleón y las visitadoras (1999). Ambas películas se hallan en la Filmoteca Española, en Madrid; de la primera, existe el negativo original y de la segunda, se ha encontrado un inter negativo. Estas tres películas forman parte del próximo proyecto de digitalización (Comunicación personal, E. Moscoso Manrique, 22 de junio de 2019).

De ahí en adelante, se inicia una etapa diversa tanto en tecnología como en producción. La primera película rodada por Lombardi en formato digital fue Ojos que no ven (2002). Sin embargo, ésta ya formaba parte del proyecto de digitalización que presentó en 2018 al Ministerio de Cultura. Esto se debe a que se tuvieron que hacer copias en $35 \mathrm{~mm}$ para su exhibición comercial, pues los proyectores digitales aún no eran la norma por aquella época. Uno de los socios de la coproducción, Javier Valiño, quien desarrolló el resto de su carrera en Chile, hizo lo posible para que le enviasen el material original, hasta que declaró que ya no existía. El trabajo de recuperación consistió, en este caso, en buscar una copia en acetato. Por suerte, encontraron dicho material en la Filmoteca Española: el 'negativo original' de la copia del material digital. Lombardi declara que luce diferente, que "visualmente no es la calidad ideal que tienen las otras; pero, por otro lado, tiene la ventaja de que se ve como cine. No parece que viniera de un digital. La imagen está un poquito lavada y sin la definición nítida de las otras películas”.

\footnotetext{
${ }^{28}$ Copia del negativo obtenida del interpositivo, que es a su vez, una copia del negativo original. Se usa para extraer copias sin dañar el negativo. Fuente: https://glosarios.servidor-alicante.com/lenguajecine/internegativo.
} 


\subsubsection{Debate alrededor de la preservación digital}

Sobre la mesa se dispersan una serie de consideraciones alrededor de lo que 'preservar' realmente significa y cómo, en el caso de este tipo de proyectos que contemplan la digitalización como método para salvar películas, el término para algunos especialistas en conservación o historiadores del cine no sería aplicable. Sin embargo, habría que evaluar qué tan posible resulta ejecutar otras acciones en este caso particular y en la situación institucional de un país en que no existe una cinemateca nacional ni otro tipo de facilidades.

Por otro lado, surgen consideraciones éticas sobre la manipulación del material. Por ejemplo, Lombardi nos explica que deseaba realizar un trabajo más detallado de corrección en España, ya que, tras el traspaso de analógico a digital de sus películas, obtuvo una copia sin tratamiento alguno, con un color plano. "Y el proceso de colorizado tenía otro costo, al igual que el posterior proceso de estandarización, donde todas estas rayitas, sobre todo las que se marcan en los inicios y finales de rollos, son tratados", menciona Lombardi. Emilio Moscoso habló también de un proceso conocido como 'ventanilla líquida'. En el Diccionario Técnico Akal de Cine, lo definen como una “(...) máquina de copiado en la que, en el momento de la exposición, la película se mueve a través del líquido que hay en una celda de vidrio, el cual rellena cualquier ralladura, impidiendo con ello que la refracción de la luz forme una imagen de las ralladuras en la nueva película" y, hablan, adicionalmente, de un proceso similar en una copiadora de ventanilla húmeda, en la que “(...) las ralladuras se llenan con un líquido inmediatamente antes de la exposición" (Konigsberg, p.570, 2004). Sin embargo, este tratamiento es netamente fotoquímico y sólo ciertas cinematecas y laboratorios podrían hacerse con máquinas de este tipo y personal calificado para su uso. Claro que hay también softwares especializados que ahora realizan labores de limpieza de rayones y polvo cuadro por cuadro, así como corrección de estabilidad y ruido del grano en las trasferencias digitales. Sin embargo, la lógica es similar: es costoso y su manejo no es tan sencillo. Además, el problema del negativo en mal estado persistiría.

El respetar la visión original, tanto del director como del fotógrafo, tampoco es una tarea infalible. En el caso evaluado, se tuvo que apelar a la memoria y también a copias en DVD con las que Lombardi contaba para orientar un poco al colorizador. En el caso de La ciudad y los perros, el Director de Fotografía, José Luis Flores Guerra sí 
participó en la re-colorización que se hizo en Guarango. También acompañó este proceso en Sin compasión.

Una transferencia en $4 \mathrm{~K}$ da mayores opciones al momento de tratar el color y ello podría acarrear una modificación sustancial de la obra. Sin embargo, se ha tratado de mantener, en la medida de lo posible, la manera en que originalmente fue vista. El único caso en que se obtuvo un resultado diverso con el color fue con Bajo la piel. Como propuesta del fotógrafo, se trabajó en el laboratorio una suerte de desaturación de imagen. Esta idea es reforzada por la descripción del filme que Bedoya otorga en su diccionario de películas peruanas. Sintetiza la concepción de la fotografía, en principios basados en "la desaturación del color, en la eliminación de los tonos cálidos y en la concentración asimétrica de proporciones de luz en un decorado iluminado en clave muy baja, para dar la expresión visual adecuada a ese universo ensimismado" (Bedoya, 1997, p. 312). Sin embargo, al volver a colorizar, estos tonos originales han sido reemplazados por cromaticidades marrones; resultado que, en palabras del mismo Lombardi, es "interesante y diferente"; aunque, reitera, no es su intención salirse de lo que auténticamente serían sus filmes para 'mejorarlos'.

Si bien existe un convenio con la empresa Guarango para hacer la colorización, no es posible realizar la limpieza ni la estandarización minuciosa del material, debido a que no se cuentan con los equipos necesarios. Las películas, a pesar de tener una apariencia general admisible, cuentan con algunos espacios donde se evidencian pequeñas rayas. Eso no resultaría adecuado si se buscase vender a empresas como Netflix; para ello sí tendría que realizarse el procedimiento completo de restauración. Por ahora, los proyectos que ha venido impulsando Lombardi se han enfocado en obtener copias colorizadas y de buen nivel, aunque con pequeñas imperfecciones, en DCP, en BluRay y en DVD, de manera que se puedan distribuir en salas de proyección y para reproducciones caseras.

El panorama al que nos enfrentamos es la relativa seguridad de que algunos de los negativos de estas películas se conservan en los depósitos de Cinecolor, en Argentina, y en la Filmoteca Española. En caso que suceda algo con las copias digitales, se puede recurrir al material original. En cuanto a Los amigos, el negativo no se encuentra, pero existe una copia que resguarda la Filmoteca PUCP y que se ha encargado de recuperar. En un estado muy crítico se hallaría el futuro de Muerte al amanecer y Muerte de un magnate, cuyas copias no resultan, al momento, ubicables. 
Al respecto, Lombardi entró en conversaciones con el personal de Guarango sobre la compra de la máquina para realizar cintas LTO que, de acuerdo con la información que manejan, permite conservar una película con una garantía de treinta años. El DCP vendría a ser un sistema más inestable. Alegan a la seguridad que las cintas LTO brindan a los archivos, así como al hecho de que no es una inversión tan grande, aunque sí habría que tener un mercado para compensar esos gastos, según nos cuenta. Existe cierto escepticismo sobre quiénes podrían estar interesados en conservar sus películas de esta manera, sobre todo cuando se trata de cineastas más jóvenes, a quienes el miedo de ver desaparecer su trabajo no se ha asomado aún.

De igual forma, permanece al aire la cuestión de dónde sería depositado este material. Podría ser, quizá, en almacenes habilitados por Guarango, en custodia en la Filmoteca PUCP, en el mismo Ministerio de Cultura o en algún otro depósito que tendría que estar condicionado para tal propósito. Por otro lado, dados los cambios tecnológicos, habría que seguir cuestionándose si esta modalidad de preservación digital resulta ideal. En dicho sentido, son necesarios los consensos entre los archivos y los productores de las cintas y drives para establecer un estándar.

Entre otras cuestiones sobre la polémica, vale reconocer que calidad en la reproducción de las características de lo fílmico en una copia digital es cada vez más fiel. La experiencia se torna muy similar, aunque no idéntica. Ambos soportes no poseen la misma materialidad. De hecho, quien vea los rollos, podrá ver en sí la película. Pero esto no sucede con la información binaria de los discos de almacenamiento digital. ¿Pero qué sería lo más conveniente, si no se cuentan aquí con los negativos? Resulta disparatado pensar en mandar a revelar, en los países que alojan los negativos, copias en material analógico para conservarlas acá, si no contamos en nuestro país con los recursos necesarios.

$\mathrm{Al}$ respecto, retomamos el caso de Ojos que no ven, grabada en digital, pero exhibida y recuperada por una copia en $35 \mathrm{~mm}$. Esto nos hace preguntarnos, cualitativamente, qué tan diferente es uno de otro y a qué clase de pérdidas nos enfrentamos cuando 'se traiciona' el formato original en la reproducción de una película. Asimismo, en tanto el propósito es preservar, y el preservar asume la autenticidad como una de sus divisas, ¿qué pasaría si una reproducción digital llegase a emular, visualmente, todas las características de una reproducción fílmica? 
Quizá el valor del original sea más claro en otras disciplinas, como la escultura. Si un escáner y una impresora 3D fuesen capaces de identificar cada detalle de una pieza y reproducirla de manera exactamente igual, esta copia seguiría sin tener el valor del original; por un lado, porque el mercado artístico así lo ha definido y, por otro, porque claramente la pieza fue tallada manualmente y tiene el valor agregado del trabajo y el espíritu humano. Esto no sucede con una película. El rollo es algo que no ve directamente el espectador: éste aprecia las imágenes ya proyectadas, independientemente de que sean reproducidas a partir de fotogramas o de códigos digitales.

Es claro que, para efectos de una preservación, lo que se desea conservar es el original. Este es el material desde el que se registró directamente la imagen. Ya al momento del acceso y de la distribución, se recurre a otros formatos, salvo en casos como eventos especiales como el festival italiano Il cinema ritrovato. En cuanto a lo nativamente digital, no existe una claridad respecto a qué soporte sería mejor para preservarlo. Más que 'perspectivas', es una cuestión de estrategias, resulten éstas más o menos ortodoxas para algunos, pues dependen, entre otras cosas, de contextos institucionales y de la prioridad de todo archivo: asegurar la supervivencia de las películas por el máximo tiempo posible y en las condiciones que aseguren una reproducción lo más cercana posible a sus características originales. 


\section{CONCLUSIONES}

Esta investigación es solo un ápice de toda la información que se encontraba a diario y que, por cuestiones de espacio y tiempo, no se pudieron incorporar al texto. De igual manera, por razones metodológicas, el tema tuvo que acotarse al punto de centrarse en un director. Habría que considerar también que muchas de estas historias se encuentran estancadas: hay archivos cuyo paradero se desconoce, algunos directores y otros protagonistas de la época ya no se encuentran entre nosotros, prima el desconocimiento de los cineastas en cuanto al tema, etc.

Se podría pensar también que, dada la antigüedad de algunos materiales que se buscan preservar, o la tecnicidad del asunto, este es un tema terminante. A pesar de eso, encontramos no solo entre teóricos, sino en la práctica, que las investigaciones son extensibles y que las consideraciones éticas sobre el filme y el patrimonio entran también a tallar en la manera en que los archivos operan. Es decir: esto no acaba en temperaturas o porcentajes de humedad; en primer lugar, porque no es posible todavía determinar con certeza cuáles son las condiciones óptimas (a pesar de la existencia de consensos, hay una pluralidad de instituciones que marcan sus estándares de acuerdo con las posibilidades y a las particularidades de sus archivos) y en segundo lugar, porque la continuidad en la labor depende de políticas que aseguren su financiamiento.

A partir de lo investigado, y aplicado a nuestra realidad, concluimos que:

- Dispersión definiría, de manera más o menos cercana, el campo de la preservación fílmica en nuestro país. Ha sido un tema muy abandonado a nivel estatal, con propuestas todavía tan primigenias como dejadas a un criterio medio intuitivo y de soluciones a corto plazo. Pero uno de los mayores problemas es la falta de integración de propuestas. Propuestas, de las cuales hubo unas tantas y todavía las hay, aunque mayormente no se han encontrado entre sí para alimentase profesionalmente. Además, han trastabillado por falta de recursos económicos. Hace falta una suerte de "unión de fuerzas" que ejerza una presión en la elaboración de políticas en el sector. 
- En el caso del material fílmico, lo que queda claro es que la preservación involucra una serie de acciones que aseguran la supervivencia del material original, así como la posibilidad de reproducir y difundir de manera indefinida. Aunque existen disidencias entre conservadores sobre la manera más eficiente y/o correcta de llevar a cabo este cometido, es cierto que desdeñar algunas prácticas porque 'no son la solución definitiva' es una actitud contraproducente. Si bien lo digital no implica una respuesta sobre la que se ponen las manos al fuego, se convierte en al menos una opción para producir una copia, cada vez más fiel a la original, debido a la calidad de los escáneres. Y ello no solo funciona como una copia de respaldo, sino como una manera más segura y simple de hacer llegar al público un material valioso. Resulta apresurado y apocalíptico aventurarse a decir que no es una alternativa. Hay obras de arte que solo se conocen por posteriores reproducciones, como las copias romanas, en mármol y bronce, de esculturas griegas que se perdieron o cuyo metal fue fundido para ser reutilizado. Si bien no estamos frente al mismo objeto, gracias a estas piezas podemos darnos una idea de aquello que fue y dicho conocimiento puede aún llegar hasta nuestros días. Lo mismo, me parece, sucedería con las copias digitales de películas grabadas en celuloide o acetato que, creo, podrían incluso dar una experiencia más cercana en tanto la reproducción sea lo más fidedigna posible. Recordemos también que la piratería en nuestro país ha sido muchas veces el 'salvavidas' de algunos filmes que, de otra manera, nos resultarían imposibles ver.

- Dicho esto, tampoco es cierto que preservar y digitalizar sean términos intercambiables cuando se trata de material fílmico. Y, de hecho, resulta lamentable que un director no cuente con el material de sus películas en su propio país, salvo por la Filmoteca PUCP, que sí custodiaría algunas copias. La conservación de los negativos queda a cargo de los depósitos y archivos, donde, al menos en el caso de la Filmoteca Española, se encuentran en buen resguardo. 


\section{RECOMENDACIONES}

Brindar recomendaciones para un tema tan vasto y que requiere de gastos igual de ingentes, es un tanto delicado. Se ha intentado recoger un par de propuestas que merecen especial atención por ser viables y por corresponder, creemos, a un punto de partida de políticas perdurables y soluciones más categóricas.

\section{Recomendación 1}

Una buena iniciativa para comenzar a promover la inversión, así como enfocar parte de la problemática del cine en nuestro país hacia la preservación, sería a través de la generación de conciencia civil sobre el patrimonio audiovisual. Mientras que su valor no se evidencie a ese nivel, los esfuerzos continuarán resultando obstaculizados y cuestionados por su verdadera repercusión en la sociedad. Estas propuestas pueden surgir, en paralelo, del sector privado y público.

\section{Recomendación 2}

Desde el Estado, se deben continuar con los proyectos ya iniciados de los concursos de proyectos de preservación, así como a los de apoyo a la formación profesional en archivo. Sin embargo, estos deberían ser potenciados por parámetros mejor definidos. Igualmente, el concurso de investigación también debería ser un incentivo para profesionales, investigadores y catedráticos hacia la continuación de las indagaciones en torno a la preservación audiovisual. Eventualmente, se considera que ciertos estímulos económicos deberían ser directos y no sujetos a concursos, cuando la institución constituya un aval y el material a rescatar sea considerado de mayor interés o de emergencia, de acuerdo con una curaduría.

\section{Recomendación 3}

Es necesaria la asistencia interinstitucional en el territorio nacional. No hay mucho que decir respecto con este punto: el intercambio profesional y tecnológico no puede hacer otra cosa sino agilizar todo el trabajo acumulado. Las instituciones y archivos 
no deben ser pensados como islas, pues, en conjunto, constituyen la memoria de un país. Tampoco se debe separar el trabajo entre sector privado y público, como si fuesen incompatibles sus propósitos. Una visión colaborativa es lo más sensato cuando los recursos escasean. Esto es, entre tantas cosas, lo que la FIAF viene a representar: una alianza.

\section{Recomendación 4}

El ámbito de las películas y grabaciones caseras es otra área de interés que no ha sido abordada aún en nuestro país y que merecería también tratarse. ¿Dónde quedarán todas esas memorias familiares que, con el tiempo, se tornan memoria colectiva; una experiencia que va más allá de la privacidad del hogar? Como el proprio Paolo Cherchi refiere, sobre todo en cuanto a aquellas películas grabadas en pequeño formato (16 mm, $8 \mathrm{~mm}$ y super 8 ), son una suerte de "instantáneas de la vida cotidiana" y, por ende, "un documento invaluable". Posee un fin sentimental y otro histórico, como una forma de investigar cómo era la vida en el siglo XX (Arcoiris TV Channel, 2014). Quizá ese podría ser uno de los ejes de promoción del patrimonio audiovisual - un proyecto que surge de la ciudadanía y que le sirve directamente--

\section{Recomendación 5}

Por último, habría que hacer un llamado a las instituciones educativas para que tomen un papel activo en la cuestión de la preservación fílmica. Muy importante es la participación de aquellas que cuentan con un programa relacionado (como lo es la Comunicación Audiovisual o especializaciones asociadas a la Conservación) y a aquellas que cuentan con un archivo audiovisual. Su rol en la investigación, promoción y estandarización de procesos es importante en la comunidad. 


\section{REFERENCIAS}

Arcoiris TV Channel. (10 de enero de 2004). Restauro fílmico Cherchi Usai [archivo de video]. Recuperado de https://www.youtube.com/watch?v=mmfkQK22u3M

Aubert, M. (diciembre, 1997). The president's message. Journal of Film Preservation, (55), 34.

Bedoya Wilson, R. (1997). Un cine reencontrado: diccionario ilustrado de las películas peruanas. Universidad de Lima.

Bilik, J. (27 de junio de 2016). Con el cierre del laboratorio Cinecolor termina una era. La Nación. Recuperado de https://www.lanacion.com.ar/espectaculos/cine/con-el-cierredel-laboratorio-cinecolor-termina-una-era-nid1912829

Burrows, E., Cherchi Usai, P., Giuliani, L., Trainor, K. y Wengström, J. (noviembre, 2013). A Beginners' Guide to Collection Policies. Journal of Film Preservation, (89), 25-30.

Coco, A. y Romero, J. (octubre,2017). Documenting Cinema: The Evolution of the Film Librarian. Journal of Film Preservation, (97), 47-53.

Corominas, J. y Pascual J. (1984). Diccionario crítico etimológico castellano e hispánico. Tomo $I V$. Madrid: Gredos.

Cultura Cusco celebrará el Bicentenario de la Independencia Nacional con tres proyectos de impacto regional (07 de noviembre de 2018). Andina. Recuperado de https://andina.pe/agencia/noticia-bicentenario-cusco-alista-tres-proyectos-protecciondel-patrimonio-732068.aspx

Daudelin, R. y Le Roy, E. (2008). FIAF Timeline. Recuperado de: https://www.fiafnet.org/pages/History/FIAF-Timeline.html

De Cárdenas, F. (2014). El cine de Francisco Lombardi. Una visión crítica del Perú. Santiago de Chile: Uqbar Editores.

Del Amo García, A. (enero-febrero, 2016). La conservación cultural del patrimonio cinematográfico y la investigación científica. ARBOR Ciencia, Pensamiento y Cultura, CLXXXII(717), 9-16.

Del Amo García, A. (julio, 2006). Archivos en tiempos de cambio. 62 Congreso de la FIAF, Sao Paulo, 24 y 25 de abril de 2006. Journal of Film Preservation, (71), 16-20.

Del Valle Gastaminza, F. (2013) Patrimonio cinematográfico. En J. Marcos Recio (Comp.), Gestión del Patrimonio audiovisual en medios de comunicación. (pp. 111-129). Madrid: Síntesis. 
Desssem, M. (24 de febrero de 2014). Film Preservation 2.0. The Dissolve. Recuperado de https://thedissolve.com/features/exposition/429-film-preservation-20/

Díaz Cervantes, K. (2014). El archivo audiovisual nacional: espacio de memoria e identidad (tesis para optar el título de Licenciado en Comunicación). Pontificia Universidad Católica del Perú.

Dirección del Audiovisual, la Fonografía y los Nuevos Medios. (08 de setiembre de 2017). Ministerio de Cultura crea grupo de trabajo para establecer lineamientos de preservación del patrimonio audiovisual. Recuperado de http://dafo.cultura.pe/ministerio-de-cultura-crea-grupo-de-trabajo-para-establecerlineamientos-de-preservacion-del-patrimonio-audiovisual/

Dupin, C. (abril, 2013). Last Tango in Paris: The Birth of FIAF, 1936-1938. Journal of Film Preservation, (88), 43-58.

Edmondson, R. (2002). Memoria del Mundo: Directrices (Edición revisada 2002). París: UNESCO. Recuperado de: https://unesdoc.unesco.org/ark:/48223/pf0000125637_spa

Edmondson, R. (2004). Filosofía y principios de los archivos audiovisuales. UNESCO: París. Recuperado http://www.amarc.org/documents/manuals/Archivos_Audiovisuales_ES.pdf

España, C. (14 de junio de 1998). Crónica de la destrucción del cine argentino. La Nación. Recuperado de https://www.lanacion.com.ar/espectaculos/cronica-de-la-destrucciondel-cine-argentino-nid100003

Federación Internacional de Archivos Fílmicos. (1998). Código de ética de la FIAF. Recuperado de: https://www.fiafnet.org/pages/Community/Codigo-de-Etica.html

Federación Internacional de Archivos Fílmicos. FIAF timeline. Recuperado de: https://www.fiafnet.org/pages/History/FIAF-Timeline.html

Félix-Didier, P. (2015). Que el viento no se lo lleve... fílmico, magnético y digital: la preservación audiovisual y el acceso a las imágenes en movimiento. En D. Kozak (Ed.), La imagen recobrada. La memoria del cine argentino en el Festival de Mar del Plata (pp. 13-26). $30^{\circ}$ Festival de Mar del Plata.

Ferro, M. (1980). Cine e historia. Barcelona: Gustavo Gili S.A.

Gabriel Quispe Medina (18 de setiembre de 2014). Cinema Paraíso, 17 setiembre 2014, entrevista a Irela Núñez [archivo de video]. Recuperado de https://youtu.be/F8MoZoXxAEw

Galvão, M. (julio, 2006). La situación del patrimonio fílmico en Iberoamérica. Journal of Film Preservation, (71), 42-62.

García Miranda, N. (2013). Cuando el cine era una fiesta: la producción de la Ley $N^{\circ} 19327$. Violeta Núñez Gorritti - Editor: Lima. 
Hidalgo Goyanes, P. (2013) Patrimonio audiovisual en televisión. En J. Marcos Recio (Comp.), Gestión del Patrimonio audiovisual en medios de comunicación. (pp. 53-80). Madrid: Síntesis.

Konigsberg, I. (2004). Diccionario técnico Akal de cine. Ediciones AKAL: Madrid.

Lenk, S. (comp.) (diciembre, 1997). Special Issue: Manual for Access to the Collections. Journal of Film Preservation, (55).

León Frías, I. (15 de febrero de 2019). El concurso de proyectos de preservación audiovisual de la DAFO: Un tema a debatir. Recuperado de http://www.paginasdeldiariodesatan.com/pdds/?p=5669

Ley No 26370, Ley de la Cinematografía Peruana. (26 de octubre de 1994). Recuperado del sitio de Internet de la Dirección del Audiovisual, la Fonografía y los Nuevos Medios: http://dafo.cultura.pe/wp-content/uploads/2017/05/Ley-de-la-Cinematograf\%C3\%ADaPeruana-Ley-26370-Consolidada.pdf

Marcos Recio, J. (2013) Introducción. En J. Marcos Recio (Comp.), Gestión del Patrimonio audiovisual en medios de comunicación. (pp. 15-21). Madrid: Síntesis.

Meyer, M. (diciembre, 1998). Film Restoration using Digital Technologies. Journal of Film Preservation, (57), 33-36.

Minichaplin. (24 de marzo de 2016). Alfonso del Amo, conservador de Filmoteca Española. Consejos para preservar películas [archivo de video]. Recuperado de https://vimeo.com/160201620

Núñez Gorritti, V. (octubre, 2015). El cortometraje documental peruano 1972-1980. Imagofagia. Revista de la Asociación Argentina de Estudios de Cine y Audiovisual, (12). Recuperado de: http://www.asaeca.org/imagofagia/index.php/imagofagia/article/viewFile/867/767

Perlmutter, M. (28 de abril de 2017). The Lost Picture Show: Hollywood Archivists Can't Outpace Obsolescence. IEEE Spectrum. Recuperado de https://spectrum.ieee.org/computing/it/the-lost-picture-show-hollywood-archivists-cantoutpace-obsolescence

Sorlin, P. (1991) Historia del cine e historia de las sociedades. Filmhistoria Online, 1(2), 73-87. Recuperado de http://revistes.ub.edu/index.php/filmhistoria/article/view/12152/14904

Staszczyszyn, B. (diciembre, 2016): Bolesław Matuszewski. Culture.pl. Recuperado de: https://culture.pl/en/artist/boleslaw-matuszewski

UNESCO. (1980). Recomendación sobre la Salvaguardia y la Conservación de las Imágenes en Movimiento. Recuperado del sitio de Internet de UNESCO: http://portal.unesco.org/es/ev.php$\underline{\text { URL_ID }=13139 \& U R L \_D O=D O \_T O P I C \& U R L \_S E C T I O N=201 . h t m l}$

Varios. (2012). Cámaras de filmar. De la linterna mágica al cine de alta definición. Madrid: Tikal Ediciones. 
Wiener Fresco, C. (2015). Estudio y propuesta sobre conservación y difusión del material cinematográfico y audiovisual peruano. Ministerio de Cultura del Perú.

Wschebor, I. (octubre, 2017). De cómo se re-convirtió un viejo Telecine SD en un escáner cuadro a cuadro con resolución 2K o superior en Uruguay. Journal of Film Preservation, (97), 123-126.

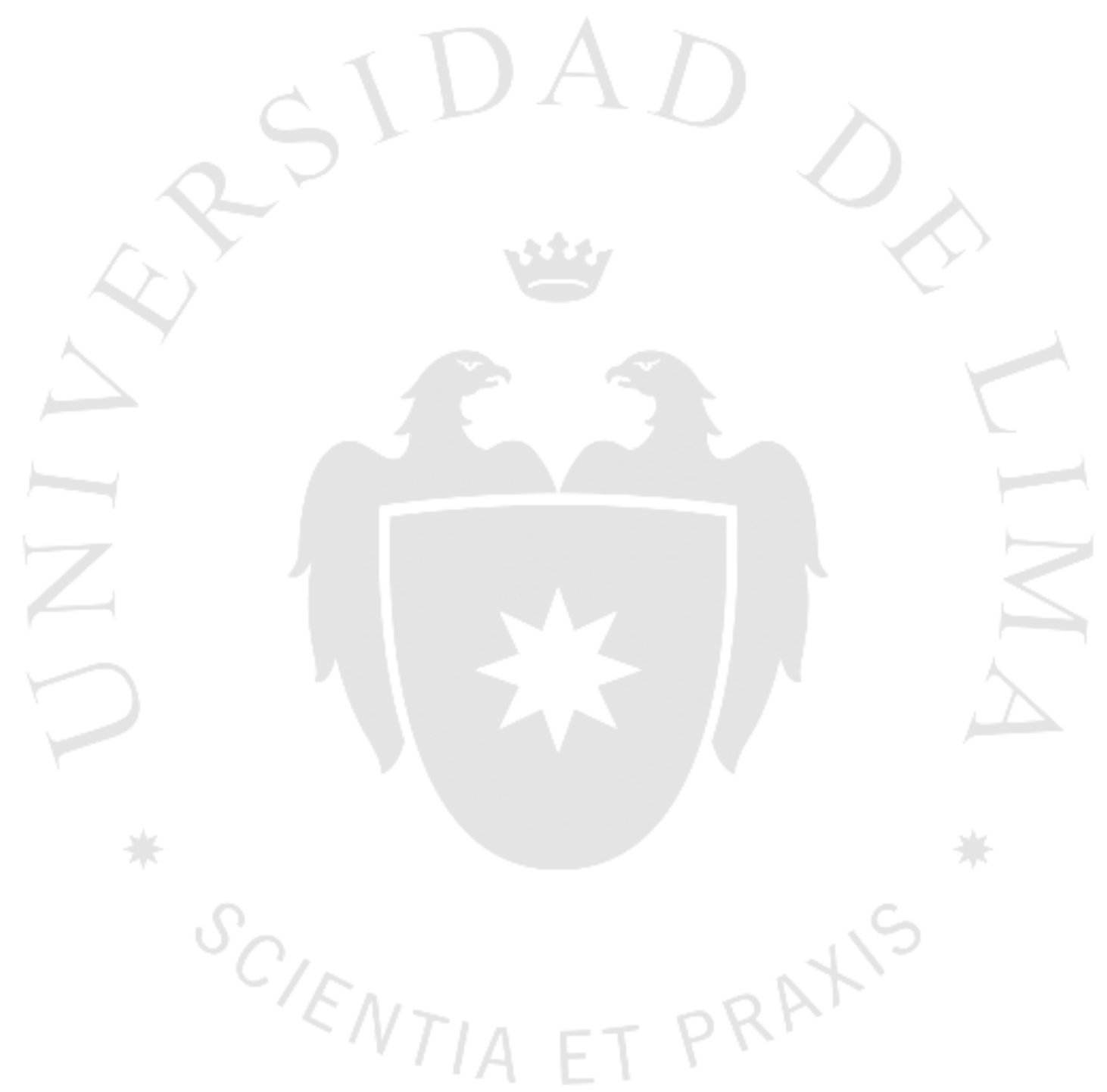




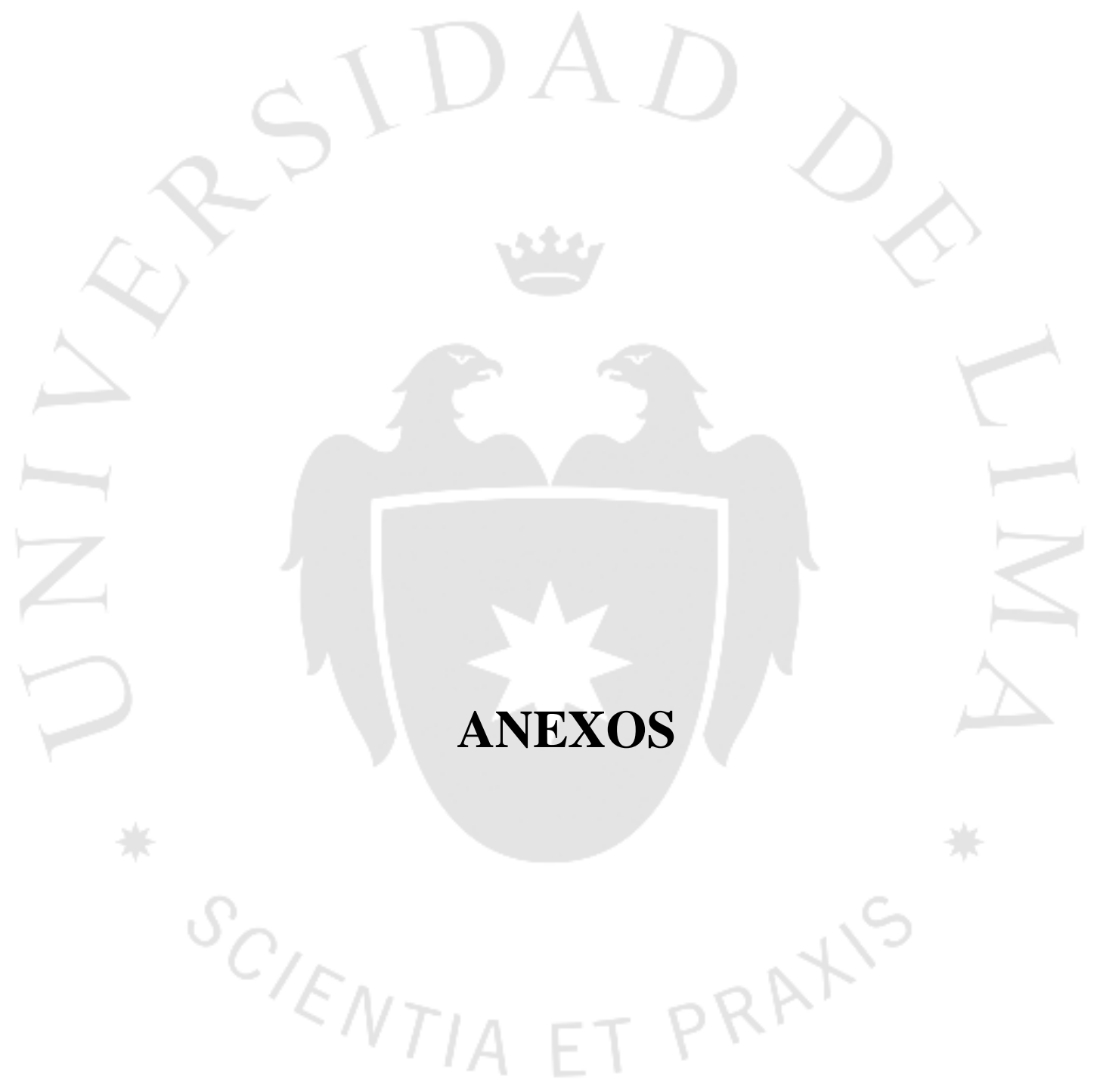




\title{
ANEXO 1: FICHAS DE LAS PELÍCULAS
}

\author{
Fichas de películas
}

Se han tomado en cuenta los largometrajes que fueron filmados de manera analógica; es decir, desde Muerte al amanecer (1977) hasta Tinta roja (2000). Las fichas se han tomado del libro El cine de Francisco Lombardi (De Cárdenas, 2014).

\section{Leyenda}

D: Dirección. G: Guión. F: Fotografía. Mús: Música. M: Montaje. DA: Dirección artística. Ass: Asistente. R: Reparto. Est: Fecha de estreno.

Muerte al amanecer. D: Francisco Lombardi. G: Guillermo Thorndike y Francisco Lombardi. F: Ramón Carty. Mús: Arturo Pinto. M: «Pili» Flores Guerra. R: Gustavo Rodríguez (Teniente Molfino), William Moreno (Gregorio Villasante, «El Monstruo»), Jorge Rodríguez Paz (director del penal), Silvia Gálvez (Techi), Hernando Cortez, Hugo Soriano, Alberto Arrese, Oscar Vega, Augusto Salazar. Producciones InCA FiLMS S.A. (Perú) - Cine Films 71 C.A. (Venezuela) - José Zavala Rey Castro - Pedro FUENMAYOR. 113 min. Est: 1977.

Mención Especial del Jurado, Festival Internacional de Cine, Locarno (1977); Mejor Ópera Prima, Festival Internacional de Cine, Cartagena (1978); Tercer Premio Coral, Festival Internacional del Nuevo Cine Latinoamericano, La Habana (1980).

Gregorio Villasante, apodado «El Monstruo» por la prensa, ha sido condenado a muerte por violación y asesinato de un niño. El fusilamiento se llevará a cabo al amanecer en una isla penal en el puerto del Callao, vecino a Lima. Faltan pocas horas y se embarcan hacia la isla el director general de Justicia, el juez instructor, el médico legista, el jefe policial, el escribano y otros funcionarios, quienes pasan la noche en la residencia del director de la prisión, cuya esposa -antigua bailarina de mambo- reanuda su relación con uno de los viajeros. Mientras, el teniente Molfino, encargado del pelotón de fusilamiento, pasea por la isla y acude a la celda del reo. Se alista el fúnebre ceremonial, Villasante grita su inocencia, culpa al juez de su condena y Molfino cumple, pese a su íntimo conflicto, las órdenes recibidas.

Cuentos inmorales. D: «Pili» Flores Guerra (El príncipe), José Carlos Huayhuaca (Intriga familiar), Augusto Tamayo San Román (Mercadotecnia) y Francisco Lombardi. Episodio: Los amigos. D y G: Francisco Lombardi. F y M: «Pili» Flores Guerra. R: Jorge Rodríguez Paz (don Jorge), Hugo Soriano (Huguito), Francisco León («Mudo» León), Augusto Salazar (El Zambo), Rosa María Lombardi (prostituta), Cecilia Noel (prostituta). Producciones Inca Films S.A. - José Zavala Rey De CASTro. Episodio de $32 \mathrm{~min}$. Est: 1978.

Cuatro amigos de infancia, vivida en una ciudad de provincia, se encuentran luego de algunos años para tomar unas cervezas y conversar. Jorge es un pequeño empresario de éxito; Hugo es un escritor frustrado que vivió algún tiempo en París; el Zambo se ha dedicado a la actuación de variedades y canta en cabarets y televisión; el «Mudo» León 
es hosco y silencioso, y al poco tiempo se va. Como fin de fiesta, deciden acudir a un prostíbulo. Allí descubren que el Zambo esconde un secreto, lo que desata la agresividad machista de Jorge. El Zambo huye, Hugo discute con Jorge y el grupo se disuelve.

Muerte de un magnate. D: Francisco Lombardi. G: Augusto Tamayo San Román y Francisco Lombardi. F: «Pili» Flores Guerra. Mús: Fernando Prialé. M: Gian Franco Annichini. R: Orlando Sacha (Luis Barletto), Martha Figueroa (Isabel), Pablo Tezén (José Valdivia), Hernando Cortez (Toño), Oscar Vega (Lobatón), Margot López (hermana de José), Alberto Arrese (Aliago Polar), Francisco Lombardi (periodista de TV). Producciones Inca Films S.A. - José Zavala Rey De Castro. 110 min. Est: 1980.

Mención Especial del Jurado, Festival de Huelva (1982).

El empresario pesquero Luis Barletto, dueño de una cadena de periódicos y otros negocios, se encuentra en problemas. El gobierno nacionalista ambiciona sus propiedades; un sindicato le hace oposición, misteriosos vehículos lo siguen. Mantiene una relación amorosa con Isabel, su asistente y secretaria. Mientras tanto, en Chaclacayo, un jardinero cuida su casa de campo. Tiene dos hijos, uno de los cuales, José, es un muchacho tímido y feo que ha vivido una existencia cargada de humillaciones. El $1^{\circ}$ de enero de 1972, Barletto e Isabel acuden a la casa de Chaclacayo. Quieren acabar unos trabajos y descansar. Pero encuentran a José armado de una pistola y un ritual sangriento se inicia.

Maruja en el infierno. D: Francisco Lombardi. G: José Watanabe y Edgardo Russo, basado en la novela «No una sino muchas muertes», de Enrique Congrains Martín. F: «Pili» Flores Guerra. Mús: Arturo Pinto. M: Augusto Tamayo San Román. R: Elena Romero (Maruja), Pablo Serra (Alejandro), Elvira Travesí (doña Carmen), Oscar Vega (Malagua), Ismael Contreras (Orejas), Juan Carlos Alarcón (Pepe), Manuel Rodríguez (Michi), Julio Vega (Manuel), Oswaldo Fernández (Gato). Producciones InCA FILMS S.A. - FRANCISCO J. LOMBARDI - ANDRÉS NOBL. 98 min. Est: 1983.

Premio de la Organización Juvenil, Festival de Tashkent (1983); Mención del Jurado, Festival de Karlovy-Vary (1984); Mención especial del Jurado, Festival de Huelva (1983).

En un miserable lavadero de botellas conviven Maruja, una pandilla de locos y Carmen, una vieja prostituta que los explota a todos con la ayuda de un capataz que también es su amante. Maruja se enamora de Alejandro, un boxeador amateur, y busca escapar de su destino mediocre. Una pandilla de jóvenes delincuentes, que proveen al lavadero de locos recogidos de la calle para servir de mano de obra barata, desata la violencia luego de un intento de robo y saqueo. La revuelta nocturna al interior del taller es sangrienta. En la madrugada, Maruja libera a los locos, se lleva el botín que la vieja Carmen guarda con codicia y abandona el lugar con inciertas expectativas para su futuro con Alejandro.

La ciudad y los perros. D: Francisco Lombardi. G: José Watanabe, basado en la novela de Mario Vargas Llosa. F: «Pili» Flores Guerra. Mús: Enrique Irrutiaga. M: Gianfranco Annichini y Augusto Tamayo San Román. R: Pablo Serra (Alberto, El Poeta), Gustavo Bueno (Teniente Gamboa), Juan Manuel Ochoa (El Jaguar), Luis Álvarez (Coronel), Eduardo Adrianzén (El Esclavo), Liliana Navarro (Teresa), Aristóteles Picho (El Boa), 
Miguel Iza (Arróspide), Toño Vega (El Rulos), David Meléndez (El Cava), Lourdes Midreau (Pies Dorados), Ramón García (Teniente Huarina), Alberto Ísola (Mayor Garrido). ProduCCIONES INCA FILMS S.A. 114 min. Est: 1985.

Concha de Plata al Mejor Director, Festival de San Sebastián (1985); Makhila de Oro a la Mejor Película, Festival de Biarritz (1985). Coral de Bronce, Festival de La Habana (1985).

La historia tiene lugar en un colegio militar, un microcosmos social donde conviven «todas las sangres» de una sociedad tan diversa y compleja como la peruana, en el contexto de la disciplina y los valores militares. Se centra en la muerte del Esclavo, un cadete débil abusado por sus compañeros, y en la posterior investigación de ese hecho de violencia.

La boca del lobo. D: Francisco Lombardi. G: Augusto Cabada y Giovanna Pollarolo. F: José Luis López Linares. Mús: Bernardo Bonezzi. M: Juan San Mateo. DA: Martha Méndez. R: Gustavo Bueno (Teniente Iván Roca), Toño Vega (Vitín Luna), José Tejada (Gallardo), Gilberto Torres (Sargento Moncada), Antero Sánchez (Teniente Basulto), Aristóteles Picho (Chino), Fernando Vásquez (Bacigalupo), Lucio Yábar (Quispe). PRODUCCIONES INCA FILMS S.A. - GERARDO HERRERO - TORNARSOl FILMS (MADRID) FRANCISCO J. LOMBARDI. 123. Est: 1988.

Premio del Jurado, Festival de San Sebastián (1988). Segundo Premio Coral, Premio Glauber Rocha-Prensa Latina, Premio Radio Habana, Premio Caimán Barbudo y Premio de la Organización Católica Internacional de Cine (OCIC), Festival de Nuevo Cine Latinoamericano, La Habana (1988). Mejor Película, Mejor Director y Mejor Guión, Festival de Cartagena (1989); Seleccionada para el London Film Festival (1989).

La historia tiene lugar en Chuspi, un pequeño pueblo de la «zona de emergencia» asolada por el grupo armado Sendero Luminoso. Una patrulla del ejército, bajo el mando de un oficial violento y arbitrario, debe aniquilar el terrorismo a cualquier precio.

Caídos del cielo. D: Francisco Lombardi. G: Augusto Cabada y Giovanna Pollarolo, parcialmente basado en el relato «Los gallinazos sin plumas» de Julio Ramón Ribeyro. F: José Luis López Linares. Mús: Alejandro Massó. M: Alberto Arévalo. DA: Martha Méndez. R: Gustavo Bueno (Humberto, «don Ventura»), Marisol Palacios (Verónica), Elide Brero (Jesús), Carlos Gassols (Lizardo), Delfina Paredes (Meche), Jorge Rodríguez

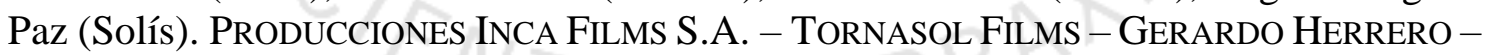
TELEVISIÓN ESPAÑOLA. 119 min. Est: 1990.

Premio a la Mejor Película, Festival des Films du Monde, Montreal (1990); Premio La Edad de Oro, Festival de Bruselas (1991); Premio Goya a la Mejor Película Extranjera, Academia del Cine Español (1991); Premio Especial del Jurado, Festival de Biarritz, 1990; Grand Prix de la XII Jornada Cinematográfica de Orleans (1990); Best Foreign Film Nomination, Academia de Artes y Ciencias Cinematográficas de Hollywood (1990).

Tres historias se entrecruzan: la de los ancianos Lizandro y Cucha, que han perdido a su único hijo, viven volcados al recuerdo y hacen lo posible para construirse un mausoleo en el cementerio; la del locutor Humberto y la depresiva Verónica, ambos solitarios y con cicatrices y deformidades corporales; y la de la abuela ciega, obsesionada con recuperar 
la vista, que maltrata y explota a sus nietos, que deben alimentar al voraz cerdo que crían en el chiquero de su miserable vivienda y que se convertirá en patíbulo.

Sin compasión. D: Francisco Lombardi. G: Augusto Cabada, basado en la novela «Crimen y Castigo» de Fedor Dostoievski. F: «Pili» Flores Guerra. Mús: Leopoldo La Rosa. M: Luis Barrios. DA: Cecilia Montiel. R: Diego Bertie (Ramón Romano), Adriana Dávila (Sonia Martínez), Jorge Chiarella (Mayor Saúl Portillo), Hernán Romero (Alejandro Velaochaga), Mariela Trejos (señora Aliaga), Marcelo Rivera (Julián Rázuri), Ricardo Fernández (Leandro Martínez). ProduCCIONES InCA FilMS S.A. - CiBY 2000 Fundación HubERT BALS - GOBIERNO DEL Distrito FEDERAL DE MÉXICO - FundACIÓN DEL NuEVo Cine LATINOAMERICANO. 127 min. Est: 1994.

Segundo Premio del Concurso de Proyectos Cinematográficos Fundación del Nuevo Cine Latinoamericano y Gobernación de México (1994); Premio a la Mejor Actuación (Diego Bertie), Festival de La Habana (1995); Catalina de Oro, Mejor Director, Festival de Cartagena (1995); Premio Mejor Director, Festival de Trieste (1995).

Ramón Romano está en prisión, condenado por el homicidio de dos personas. Decide contarle su vida al capellán de la cárcel. Estudiante universitario pobre, Romano proclama su convencimiento de que la ética es un asunto de convicción individual que nada le debe a la moral natural, y que, en nombre de esas creencias, cualquier acto está justificado. Romano se enamora de Sonia, una joven prostituta que debe alimentar a sus hermanos. Acosado por su situación económica y movido por la rebeldía ante la realidad de la mujer que ama, Romano asesina a la propietaria de la habitación que ocupa y roba el dinero de la víctima, lo que le permite ayudar a Sonia.

Bajo la piel. D: Francisco Lombardi. G: Augusto Cabada. F: Teo Delgado. Mús: Bingen Mendizábal. M: Fernando Pardo. R: José Luis Ruiz (Capitán Percy Corso), Ana Risueño (doctora Marina), Diego Bertie (Gino), Gianfranco Brero (Catalino Pinto), Jorge Rodríguez Paz (alcalde Fausto Leyva), Eduardo Yépez (fiscal Demetrio Rojas), Gilberto Torres (sargento Faura). PRODUCCIONES INCA FILMS S.A. - TORNASOL FILMS - PANDORA FILMS. 110 min. Est: 1996.

Concha de Plata, Mejor Director, Festival de San Sebastián (1996); Segundo Premio Coral y Mejor Guión de Largometraje, Festival de La Habana (1996); Mejor Actuación (José Luis Ruiz), Festival de Gramado (1997).

La historia es la de Percy Corso, un policía reservado e inseguro que debe investigar los asesinatos que suceden en Palle, una pequeña localidad al norte del Perú. Las víctimas son ejecutadas de acuerdo a los ritos moche, cultura prehispánica que practicó la decapitación. Al pueblo llega Marina, médico patóloga, quien pone a Percy tras la pista acertada. El contacto cada vez más estrecho entre Percy y Marina, que a su vez sostiene una relación con el hijo del alcalde, desata en el policía una pasión amorosa y unos impulsos bajo su piel que no es capaz de controlar. Al mismo tiempo, su relación con el asesino le muestra el lado oscuro que lleva dentro.

No se lo digas a nadie. D: Francisco Lombardi. G: Giovanna Pollarolo y Enrique Moncloa, basado en la novela «No se lo digas a nadie» de Jaime Bayly. F: Carles Gusi. Mús: Roque Baños. M: Nicholas Wentworth. R: Santiago Magill (Joaquín), Lucía Jiménez (Alejandra), Hernán Romero (Luis Felipe), Carmen Elías (Maricucha), Christian 
Meier (Gonzalo), Giovanni Ciccia (Alfonso), Carlos Fuentes (Gerardo). ProduCCIONES INCA FILMS S.A. - LOLA FILMS. 111 min. Est: 1998.

Joaquín siempre ha sabido que le gustan los hombres. Presionado por el entorno social y familiar, intenta relacionarse con Alejandra, pero se enamora de Gonzalo, con quien inicia una intensa aventura. El problema es que quiere que su amigo deje a su novia, pero Gonzalo desea casarse y continuar los encuentros a ocultas. Decepcionado por la conducta hipócrita de Gonzalo y deprimido por su ruptura con él, decide irse a Miami a buscar una vida más auténtica lejos de los prejuicios de la sociedad limeña. Pero en su nuevo destino tampoco encuentra lo que busca. Decide regresar a Lima aceptando las reglas y convenciones para integrarse socialmente.

Pantaleón y las visitadoras. D: Francisco Lombardi. G: Giovanna Pollarolo y Enrique Moncloa, basado en la novela de Mario Vargas Llosa. F: Teo Delgado. Mús: Bingen Mendizábal. M: Danielle Fillios. R: Salvador del Solar (Capitán Pantaleón Pantoja), Angie Cepeda (Colombiana), Mónica Sánchez (Pochita), Pilar Bardem (Chuchupe), Sergio Galliani (ayudante), Gianfranco Brero (General Collazos), Tatiana Astengo (visitadora), Gustavo Bueno (Coronel López), Aristóteles Picho (El Sinchi). Producciones InCA Films S.A. - AmÉrica Producciones S.A. - José E. Crousillat. 114 min. Est: 1999.

Kikito de Oro a la Mejor Película, Mejor Director y Mejor Actor, Premio del Público y Premio Fipresci, Festival de Gramado (2000); Premio Spondilus a la Mejor Película, Encuentro Latinoamericano de Cine, Lima (2000); Premio Mejor Actuación en Tróia International Film Festival; Premio del Público, Festival Internacional de Viña del Mar (2000).

El Capitán Pantaleón Pantoja, honrado, trabajador, recto, honesto esposo y hombre dedicado a su institución, altamente disciplinado y gran organizador, es enviado por sus superiores a Iquitos con una misión secreta: montar un servicio ambulante de prostitutas para la zona de frontera en la selva amazónica y aliviar así los ímpetus de la tropa. Lo reservado de su misión obliga a Pantaleón a ocultar las cosas a su esposa Pochita. Todo va bien hasta que Pantaleón se enamora de la bella Colombiana y el venal locutor radial El Sinchi hace público el tinglado. Un confuso incidente termina por complicar las cosas para Pantaleón, quien después de pronunciar en el cementerio un responso en uniforme por la Colombiana, liquida toda posibilidad de conservar su secreta misión.

Tinta roja. D: Francisco Lombardi. G: Giovanna Pollarolo, basado en la novela de Alberto Fuguet. F: Teo Delgado. Mús: Bingen Mendizábal. M: Danielle Fillios. R: Gianfranco Brero (Saúl Faúndez), Giovanni Ciccia (Alfonso Fernández), Fele Martínez (Escalona), Lucía Jiménez (Nadia), Carlos Gassols (Van Gogh), Ivonne Frayssinet (Rosana), Hernán Romero (Ortega), Tatiana Astengo. ProduCCIONES INCA FILMS S.A. AmÉricA Producciones S.A. - TORNASOl FilmS - GERARdo HERRERO. 110 min. Est: 2000.

Mejor Director y Premio Vigía, Festival Internacional del Nuevo Cine Latinoamericano de La Habana (2000); Concha de Plata al Mejor Actor (Gianfranco Brero), Festival de San Sebastián (2000); Mejor Guión, Festival de Los Ángeles (2001); Mejor Guión, Festival Internacional de la India (2001). Segundo Premio a la Mejor Película, Encuentro 
de Cine Latinoamericano, Lima (2001); Golden Reel Award, Miami Film Festival (2001).

Recién salido de la escuela de periodismo, Alfonso Fernández sueña con ser escritor, mientras debe conformarse con hacer sus prácticas pre profesionales en el diario sensacionalista El Clamor. Allí será destinado a la sección policial y deberá enfrentarse al curtido editor Saúl Fernández, quien se mueve cómodamente entre cadáveres y sangre. Alfonso se resistirá a aceptar la dudosa moral con que su jefe se enfrenta a los hechos del día a día. Pero gradualmente, a medida que descubra con nuevos ojos la ciudad, sus gentes y la dura realidad del trabajo y la vida, empezará a entender mejor y de otra manera las cosas. Faúndez, que ha bautizado a Alfonso con el sobrenombre de «Varguitas», abrirá, a su vez, las pesadas puertas de su intimidad. 